\title{
The Many Elements of Traditional Fire Knowledge: Synthesis, Classification, and Aids to Cross-cultural Problem Solving in Fire- dependent Systems Around the World
}

\author{
Mary R. Huffman ${ }^{1}$
}

\begin{abstract}
I examined the hypothesis that traditional social-ecological fire systems around the world include common elements of traditional fire knowledge (TFK). I defined TFK as fire-related knowledge, beliefs, and practices that have been developed and applied on specific landscapes for specific purposes by long time inhabitants. In all, 69 distinct elements of TFK were documented in 35 studies, including accounts from 27 countries on 6 continents. On all 6 continents, 21 elements (30\%) were recorded, and 46 elements (67\%) were recorded on 4 or more continents. The top 12 most commonly reported elements, which were included in $>50 \%$ of the studies, were fire effects on vegetation; season of the year; fire effects on animals; moisture of live or dead fuels; the onset or end of rainy season, dry season, or timing of rain; burning illegal or regulated by central government; fire intensity, heat output, i.e., hot or cool fire; frequency, return interval, time since fire; fire control; firebreaks, barriers; consequences of not burning; and plant or animal phenology. Traditional fire knowledge was multifaceted: 13 studies included more than 25 elements. Practicing traditional fire management also entails understanding the ways in which multiple elements interact and influence one another. Three classification systems provide insight into TFK systems, including typologies of agroecological type, pre- and postindustrial anthropological fire regimes, and viability status. The longevity of traditional fire knowledge and practice faces serious threats at precisely the time when climate change promises disruptions in fire activity that will be problematic for indigenous and nonindigenous societies alike. Central governments tend to adopt the pathological response of command and control during times of fire increase, further constraining traditional fire management. The opposite is needed: to seriously engage traditional practitioners in solving fire problems of global significance.
\end{abstract}

Key Words: ecological anthropology; fire management; indigenous; pyrogeography; traditional ecological knowledge; traditional fire knowledge; wildland fire

\section{INTRODUCTION}

This synthesis and classification of traditional fire knowledge (TFK) was inspired by a conversation with Stephen Pyne about traditional fire management practices in southern Mexico, in which he reflected that "People all over the world have figured these things out." (S. J. Pyne, personal communication, 2009). 'These things' were the relationships among burnable vegetation, weather, and landforms, i.e., the fire environment articulated by Countryman (1966), and how to manipulate fire's effects upon plants, animals, and the human living environment. In response, I posited a simple hypothesis: that traditional fire practitioners all over the world use common elements of fire knowledge. Three goals evolved for the project: (1) to make the worldwide sophistication of traditional fire knowledge better known; (2) to provide a list of elements that researchers and practitioners can use to explore and engage TFK more readily, even if they do not have prior knowledge of fire-related variables; and (3) to inspire fire regulators, policy makers, and site managers to simply reach out and ask neighboring traditional fire managers to help solve complex fire problems in fire-dependent social-ecological systems.

Recognizing inherent ambiguities in the concept, Berkes (2012:7) provides a working definition of traditional ecological knowledge (TEK): “a cumulative body of knowledge, practice, and belief, evolving by adaptive processes and handed down through generations by cultural transmission, about the relationship of living beings (including humans) with one another and with their environment." Fernandez-Gimenez (2000) further specifies that TEK is knowledge held by particular groups of people from specific places. A subset of TEK is TFK, which I define as fire-related knowledge, beliefs, and practices that have been developed and applied on specific landscapes for specific purposes by long time inhabitants. Further, I define traditional fire knowledge systems as those social-ecological systems that depend upon the application of TFK in practice, i.e., putting fire on the ground, to stay viable in the long run. Contrasting TFK from long time human observation of fires ignited by nonanthropogenic sources, i.e., lightning or volcanos, TFK assumes purposeful burning, and "the application of fire to particular vegetation areas under specified conditions to achieve select cultural purposes" (Anderson 2005:135).

Traditional fire knowledge systems are threatened by multiple stressors including shifts in the demography of traditional fire cultures, land use change, unsupportive policy, and climate change (González 2001, Mistry et al. 2005, Rai et al. 2007, Seijo and Gray 2012). Scholars have called upon scientists 
and governments to preserve TEK and, further, to employ it as a useful complement to western scientific knowledge in natural resource management settings (Pimbert and Pretty 1995, Whitehead et al. 2003, Oltremari and Jackson 2006). Some authors have extended this call to include traditional fire management specifically (Cairns and Garrity 1999, Pivello 2011).

Case studies of indigenous people's use of fire have led to mostly written recognition that it is rich and useful (Rai et al. 2007, Seijo et al. 2011). Traditional fire managers provide important services, such as moderating fuel loads, maintaining biodiversity, maintaining watersheds, and revitalizing firedependent cultures. Although it is most common for governments to support programs that focus on fire prevention, including avoiding or restricting traditional fire practices (Moore et al. 2002, FAO and Project FireFight South East Asia 2003, CONAFOR 2009), there are also instances in which utilizing TFK or at least collaborating with traditional practitioners in fire management is recommended (Jurvélius 2004, McDaniel et al. 2005; R. Vélez, unpublished manuscript). The case of Australia stands as a progressive example in which indigenous fire knowledge is being incorporated into fire management that includes goals for carbon cycling and reducing greenhouse gas emissions (Fitzsimons et al. 2012).

\section{METHODS}

I reviewed the literature on traditional burning practices recorded in 35 studies from Africa, Asia, Australia, Europe, North America, and South America. A minimum of five studies was included for each continent. Accounts from 27 countries and numerous study locations were included (Appendix 1). A wide array of social and ecological systems was represented. Ecosystems included forests, savannas, shrublands, grasslands, and wetlands at various latitudes and gradients of elevation and moisture, e.g., riparian zones to ridge tops (Appendix 1). A variety of fire-related social factors was also represented, including various forms of land tenure, fire use histories, systems of fire governance, and fire-related economies.

Studies ranged in form and content from descriptions of practices recorded by indigenous burners themselves (Garde et al. 2009), to case studies performed by outside researchers (McDaniel et al. 2005), to government documents based on officials' work in fire prevention and management (Vélez 2005). The information ranged in depth and specificity from cursory and tangential (Rodgers 1986) to intensive and highly nuanced (Kull 2002). The spatial-temporal scales of information ranged from studies of specific villages during the course of graduate studies (Otterstrom 2004, CabreraGarcía 2006, Huffman 2010), to extensive historical records at a national or continental scale, such as those compiled by Stewart et al. (2002) and Pyne (1997). These last two references included accounts taken from multiple cultures across centennial or millennial time periods. For convenience, compilations were tallied as if their contents represented a single document. In one instance, Boyd (1999) provided an edited volume including work by several authors who contributed separate studies about a single region, the Pacific Northwestern United States. Rather than repeat information from each chapter, I selected the study by Turner (1999) because it provided the most specifics regarding elements of TFK.

I developed the list of elements of TFK (Table 1) building upon the study of "factors of fire" utilized by traditional fire managers in the Mesoamerican tropical pine-oak forests of Chiapas, Mexico provided by Huffman (2010). I read subsequent studies with those factors in mind, and added or revised descriptions of elements that were detectable in the other studies. When authors recorded similar fire concepts in slightly different terms, e.g., the onset of the rainy season versus the timing of rain, I broadened the description to be inclusive. I strictly avoided inferences, refusing to tally elements that were not described in writing, even if knowledge of one variable would logically require knowledge of another. For example, knowing that fires die down at night might infer knowing something about temperature or relative humidity. Elements were grouped into seven categories revised from Huffman (2010): geology, topography, and soils; vegetation and fuels; weather; fire behavior; fire operations; fire effects; and governance and other social factors. I excluded "purpose of burning" as a category because this information is published in nearly all studies of TFK, and as such does not need to be repeated here. The cognitive framework for identifying, naming, and categorizing these elements was derived from my North American, postindustrial perspective and experiences with social-ecological fire systems.

\section{RESULTS}

Because the literature varies widely in methods, content, and specificity, I caution against all but the coarsest quantitative characterizations. A simple example to illustrate the impracticality of numerical comparisons is provided by noticing the incongruities between the information in Pyne (1997) and that in Garde et al. (2009). The elements in Pyne are gleaned almost entirely from historical accounts, whereas those from Garde et al. are based on interviews with living practitioners. There is a variety of vegetation types included in each reference, but the European types occur in temperate to boreal biomes, whereas the vegetation in Australia occurs in temperate to tropical biomes. Even the simplest geopolitical boundaries, those of continent and country are problematic. Each reference addresses its respective continent; however, the elements of TFK gleaned from Pyne (1997) are from eight European countries that are relatively small in geographic extent, whereas Garde et al.'s work necessarily includes only one very large country. The data provided in the tables and 
Table 1. Summary by continent of the elements of traditional fire knowledge recorded in 35 studies that included accounts from 27 countries.

\begin{tabular}{|c|c|c|c|c|c|c|c|}
\hline & $\begin{array}{c}\text { Africa } \\
\text { Composite }\end{array}$ & $\begin{array}{c}\text { Asia } \\
\text { Composite }\end{array}$ & $\begin{array}{c}\text { Australia } \\
\text { Composite }\end{array}$ & $\begin{array}{c}\text { Europe } \\
\text { Composite }\end{array}$ & $\begin{array}{l}\text { N. America } \\
\text { Composite }\end{array}$ & $\begin{array}{l}\text { S. America } \\
\text { Composite }\end{array}$ & $\begin{array}{c}\text { Total number of } \\
\text { studies recording } \\
\text { each element }\end{array}$ \\
\hline Element of Traditional Fire Knowledge & $\begin{array}{c}(n=6) \\
6 \text { countries }\end{array}$ & $\begin{array}{c}(\mathrm{n}=6) \\
5 \\
\text { countries }\end{array}$ & $\begin{array}{c}(\mathrm{n}=5) \\
1 \\
\text { country }\end{array}$ & $\begin{array}{c}(n=5), \\
8 \text { countries }\end{array}$ & $\begin{array}{c}(\mathrm{n}=8) \\
3 \text { countries }\end{array}$ & $\begin{array}{c}(n=5), \\
4 \text { countries }\end{array}$ & $\begin{array}{c}(n=35), \\
27 \text { countries }\end{array}$ \\
\hline
\end{tabular}

Geology, Topography, Soil

Soil type, moisture

Slope

Geologic substrate, landform

Elevation

Aspect

Soil temperature, frozen or thawed

Vegetation, Fuels

Moisture of live or dead fuels

Plant or animal phenology

Fuel composition, species

Fuel load

Fuel or vegetation structure, arrangement, continuity,

height

Fuel consumption: degree, speed, patchiness

Fuel diameter or size (e.g., logs vs. grass)

Vegetation type

\section{Weather}

Season

Onset or end of rainy season, dry season, timing of

rain

Wind speed, force

Wind direction, source

Temperature

Humidity of air, day

Water level, stream flow, river cycle

Quantity of rain

Snow or ice location, condition (including melting or

$\begin{array}{lll}X & X & X \\ X & X & X \\ & X & X\end{array}$

breakup)

Lightning

Phase of moon

Sun's force and position in sky

Clouds

Fire Behavior

Fire intensity, heat output (hot or cool fire)

Frequency, return interval, time since fire

Fire size, area, aerial extent

Fire type (surface, ground, canopy)

Backing, heading fire

Direction of fire spread (including landmarks)

Flame height

Rate of spread

Natural extinguishment

Residence time

Evenness, smoothness

Spotting, sparks, embers carried aloft

Fire Operations

Control

Firebreaks, barriers

Time of day

Landscape pattern, patch size

$\mathrm{X}$

X $\quad X \quad X$

$\mathrm{X}-\mathrm{X}$

$X \quad X \quad X$

$\mathrm{X}$

$\mathrm{X}$

$\mathrm{X}-\mathrm{x}$

$\mathrm{X} \quad \mathrm{X}$

X $\quad$ X $\quad$ X

X

$\mathrm{X}$

$\mathrm{X}$

$\mathrm{X}$

$\mathrm{X}$

$\mathrm{X}$

$\mathrm{X}$

X

X

X

$\mathrm{X}$

$\mathrm{X}$

X

X

X $\quad$ X

$\mathrm{X}$

$\mathrm{X}$

$\mathrm{X}$

$\mathrm{X}$

$\begin{array}{ll}X & X \\ X & X\end{array}$

X

X

$\mathrm{X}$
$\mathrm{X}$
$\mathrm{X}$

X X

$\mathrm{X}$

X

14

10

5

3

2

X

X

$\mathrm{X}$

$\mathrm{X}$
$\mathrm{X}$

22

18

16

14

14
14

12

X

$\mathrm{X}$

X

X $\quad X$

X

$\mathrm{X}$

X X

$\mathrm{X}$

$\mathrm{X}$

$\mathrm{X}$

X

$\mathrm{X}$

X

$X$
$X$
$X$
$X$

X

X

X $\quad X \quad 20$

$\begin{array}{lll}X & X & 20\end{array}$

$\begin{array}{lll}\mathrm{X} & \mathrm{X} & 14\end{array}$

X

$\begin{array}{lll}\mathrm{X} & \mathrm{X} & 12 \\ \mathrm{X} & \mathrm{X}\end{array}$

$\begin{array}{lll}X & X & 8 \\ X & X & 7\end{array}$

X

$\begin{array}{ll}X & 6 \\ X & 5\end{array}$

$\begin{array}{ll}X & 5 \\ X & 2\end{array}$

X

X 2

$\begin{array}{lllllll}\text { X } & \text { X } & \text { X } & \text { X } & \text { X } & \text { X } & 20 \\ \text { X } & \text { X } & \text { X } & \text { X } & \text { X } & \text { X } & 19 \\ \text { X } & \text { X } & \text { X } & \text { X } & \text { X } & \text { X } & 16 \\ \text { X } & \text { X } & \text { X } & \text { X } & \text { X } & \text { X }\end{array}$

(con'd) 
Tools for preparation, ignition, control

Crew size, use of neighbors

Ignition pattern

Spatio-temporal sequence of fires, including for

prevention

Danger, risk, destructive potential

Fire placement

Planning, monitoring conditions prior to burning

Site preparation

Fire duration

Special clothing

Fire Effects

Fire effects on vegetation

Fire effects on animals

Consequences of not burning

Fire effects on soil

Smoke effects, smoke color, smoke column

characteristics

Scorch height, bark char, smoked leaves

Fire effects on watershed, water delivery

Fire Governance, Other Social Factors

Burning illegal or regulated by central government

Gender roles in fire management

Land stewardship, care, cleaning up country,

controlling space

Knowledge transmission

Burning regulated internally by community

Fire as tool in social resistance, protest, local conflict

Authority, decision to burn

Age of participants

Prohibited areas (customary, sacred, community

safety)

Number of elements recorded

$\begin{array}{ll}\mathrm{X} & \mathrm{X} \\ \mathrm{X} & \\ \mathrm{X} & \mathrm{X} \\ \mathrm{X} & \mathrm{X} \\ \mathrm{X} & \mathrm{X} \\ \mathrm{X} & \mathrm{X} \\ & \mathrm{X}\end{array}$

$\begin{array}{ll}X & X \\ X & X \\ X & X \\ X & X \\ & \end{array}$

$\mathrm{X}$
$\mathrm{X}$
$\mathrm{X}$

X

$\mathrm{X}$

$X$
$X$

$\mathrm{X}$
$\mathrm{X}$
$\mathrm{X}$

$\begin{array}{ll}X & X \\ X & X \\ X & X \\ X & X\end{array}$

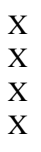

$\mathrm{X}$
$\mathrm{X}$
$\mathrm{X}$

$\mathrm{X} \quad \mathrm{X}$

$\mathrm{X} \quad \mathrm{X}$

$x-x$

$\mathrm{X}$

X

$\mathrm{X}$

X X

$X$
$X$

$\mathrm{X}$

$\mathrm{X}$

$\mathrm{X}$
$\mathrm{X}$
$\mathrm{X}$

$\mathrm{X}$

$\mathrm{X}$

$\begin{array}{lll}X & X & 15\end{array}$

$\mathrm{X}$

$\mathrm{X}$

$\mathrm{X}$

$\mathrm{X}$

$\mathrm{X}$

$\mathrm{X}$

13

13

$\begin{array}{lll}X & X & 9\end{array}$

$\begin{array}{ll}\mathrm{X} & \mathrm{X} \\ \mathrm{X} & \mathrm{X}\end{array}$

$\begin{array}{lll}X & X & 5 \\ X & X & 5\end{array}$

$\begin{array}{lll}\mathrm{X} & \mathrm{X} & \mathrm{X} \\ \mathrm{X} & \end{array}$

1

$\begin{array}{ll}\mathrm{X} & 3 \\ \mathrm{X} & 2\end{array}$

$x \quad x \quad x-x$

$\mathrm{X}-\mathrm{X}$

$\mathrm{X}$

$\mathrm{X}$

$\begin{array}{ll}X & X \\ X & X\end{array}$

$\mathrm{X}-\mathrm{X}$

$X$
$X$

$\mathrm{X}$

$\mathrm{X}$

$\begin{array}{rrrr} & \mathrm{X} & \mathrm{X} & 8 \\ & \mathrm{X} & \mathrm{X} & 8 \\ \mathrm{X} & \mathrm{X} & 8 \\ & \mathrm{X} & \mathrm{X} & 7 \\ & \mathrm{X} & \mathrm{X} & 3 \\ & \mathrm{X} & & 3\end{array}$

appendices should be used only to provide a basic and oversimplified general impression. Tallies of the elements of TFK recorded from each study are provided in Appendix 2.

The primary results are that the global body of TFK includes at least 69 distinct social and ecological elements (Table 1), and that these elements are, as Stephen Pyne observed, known by traditional fire practitioners all over the world. The top 12 most commonly mentioned elements, which were included in $>50 \%$ of the studies, were the following: fire effects on vegetation; season of the year; fire effects on animals; moisture of live or dead fuels; onset or end of rainy season, dry season, timing of rain; burning illegal or regulated by central government; fire intensity, heat output, i.e., hot or cool fire; frequency, return interval, time since fire; fire control; firebreaks, barriers; consequences of not burning; and plant or animal phenology (Table 2). It is not known if these commonly recorded elements are the most universal or important factors in traditional practice. They may be just the most easily described by the participants or the most easily discerned by the researchers.

On all 6 continents, 21 elements (30\%) were recorded, and 46 elements $(67 \%)$ were recorded on 4 or more continents (Table 1). Traditional fire knowledge was typically multifaceted: the average number of elements recorded per study was 21 .
Among the 35 studies, 6 included more than 35 elements; 13 studies included more than 25 elements. Among the less commonly recorded elements, 20 (29\%) were recorded in 5 or fewer studies. Only two elements, clouds and special clothing, were recorded in a single study. The extent to which the less commonly recorded elements are truly unusual components of TFK worldwide is not known.

Sometimes a study included an element that was common among studies, but the local expression of the element was novel or unique. For instance, traditional fire practitioners of Mayan descent in Chiapas, Mexico, indicated that they burned with a "silent wind," which was not the same as any wind at all (Huffman 2010). Thus, the element is classified in this study as simply "wind speed, force," but the local nuance and the actual meaning is that the wind was gentle enough not to make any noise in the practitioners' ears (Huffman 2010). Similar subtlety in praxis is, or was, likely present in reality for many of the traditional fire systems that received only general description in the literature.

Although it is not evident from the resulting lists, several accounts also provided evidence that traditional practitioners knew how fire variables interacted and influenced one another. In Otterstrom (2004:21), Nicaraguan farmers described how the interaction of fuels and weather influenced their decision 
Table 2. The most commonly recorded elements of traditional fire knowledge, sorted from the most common (top left) to the least common (bottom right). Elements were tallied from 35 studies that included accounts from 27 countries on 6 continents.

\begin{tabular}{|c|c|c|c|}
\hline Element of Traditional Fire Knowledge & $\begin{array}{l}\text { Number of } \\
\text { studies } \\
\text { recording each } \\
\text { element }\end{array}$ & Element of Traditional Fire Knowledge & $\begin{array}{l}\text { Number of } \\
\text { studies } \\
\text { recording each } \\
\text { element }\end{array}$ \\
\hline Fire effects on vegetation & 33 & $\begin{array}{l}\text { Land stewardship, care, cleaning up country, controlling } \\
\text { space }\end{array}$ & 9 \\
\hline Season of the year & 32 & Humidity of air, day & 8 \\
\hline Fire effects on animals & 29 & Direction of fire spread (including landmarks) & 8 \\
\hline Moisture of live or dead fuels & 22 & Fire placement & 8 \\
\hline Onset or end of rainy season, dry season, timing of rain & 22 & Knowledge transmission & 8 \\
\hline Burning illegal or regulated by central government & 22 & Burning regulated internally by community & 8 \\
\hline Fire intensity, heat output (hot or cool fire) & 20 & Fire as tool in social resistance, protest, local conflict & 8 \\
\hline Frequency, return interval, time since fire & 20 & Geologic substrate, landform & 7 \\
\hline Control & 20 & Flame height & 7 \\
\hline Firebreaks, barriers & 19 & Authority, decision to burn & 7 \\
\hline Consequences of not burning & 19 & Water level, stream flow, river cycle & 6 \\
\hline Plant or animal phenology & 18 & Quantity of rain & 6 \\
\hline Fuel composition, species & 16 & $\begin{array}{l}\text { Snow or ice location, condition (including melting or } \\
\text { breakup) }\end{array}$ & 6 \\
\hline Time of day & 16 & Rate of spread & 6 \\
\hline Landscape pattern, patch size & 15 & Elevation & 5 \\
\hline Tools for preparation, ignition, control & 15 & Natural extinguishment & 5 \\
\hline Fire effects on soil & 15 & Planning, monitoring conditions prior to burning & 5 \\
\hline Soil type, moisture & 14 & Site preparation & 5 \\
\hline Fuel load & 14 & $\begin{array}{l}\text { Smoke effects, smoke color, smoke column } \\
\text { characteristics }\end{array}$ & 5 \\
\hline Fuel or vegetation structure, arrangement, continuity, height & 14 & Lightning & 4 \\
\hline Fire size, area, aerial extent & 14 & Aspect & 3 \\
\hline Wind speed, force & 13 & Phase of moon & 3 \\
\hline Wind direction, source & 13 & Sun's force and position in sky & 3 \\
\hline Fire type (surface, ground, canopy) & 13 & Fire duration & 3 \\
\hline Crew size, use of neighbors & 13 & Scorch height, bark char, smoked leaves & 3 \\
\hline Ignition pattern & 13 & Age of participants & 3 \\
\hline Fuel consumption: degree, speed, patchiness & 12 & Prohibited areas (customary, sacred, community safety) & 3 \\
\hline Backing, heading fire & 12 & Soil temperature, frozen or thawed & 2 \\
\hline Gender roles in fire management & 12 & Residence time & 2 \\
\hline Slope & 10 & Evenness, smoothness & 2 \\
\hline Fuel diameter or size (e.g., logs vs. grass) & 9 & Spotting, sparks, embers carried aloft & 2 \\
\hline Vegetation type & 9 & Fire effects on watershed, water delivery & 2 \\
\hline Temperature & 9 & Clouds & 1 \\
\hline Spatio-temporal sequence of fires, including for prevention & 9 & Special clothing & 1 \\
\hline Danger, risk, destructive potential & 9 & & \\
\hline
\end{tabular}

about the time of day for burning: "it depends on the fuels, if there are low fuels then you burn early so that the sun will lift them up in the burn, but if there are high fuels you want to burn in the afternoon when it is fresh." In this example, the Nicaraguan demonstrates his or her understanding that the time of day, fuel height, sun's impact, and something about the air (freshness) all interact in the fire. In a second example, Bardayal Nadjamerrek, a coauthor of Garde et al. (2009:151) who is an indigenous fire practitioner himself, describes the interactions of six factors in his short reply to a question about whether or not a particular fire will kill animals on the Arnhem Land Plateau. The elements include animal effects, season, wind direction, fuel consumption or burn area, wind speed, and flame height. "[Animals] will die if you burn [spinifex in the rock country] in the middle of the late dry season [kurrung] or when the south-east winds are blowing in the early dry, then it will burn 'all over.' We should not burn when there is too much wind. When the wind has dropped, when it is finished, then you can burn it late in the afternoon, around dusk, then the flames will be lower."

Although the majority of elements were shared across socialecological systems, a few elements appeared to be regionally specific, either culturally or environmentally. In three out of five of the cases from South America, for example, authors mentioned the importance of the phases of the moon to the timing of burning. The importance of the lunar cycle to various agricultural and domestic activities is well known from that region. The position of snow or the timing of snowmelt was 
mentioned in four of the six studies from the United States and Canada, but logically not from any of the tropical areas. In the two Australian studies from Arnhem Land, Aboriginal fire managers noted differences in the character of fires above and below a prominent geologic feature, the Arnhem Land Escarpment.

\section{DISCUSSION}

The long list of elements that traditional fire managers have incorporated into their burning practices shines a bright light upon the depth and sophistication of TFK around the world. Although the level of detail within the accounts determined what elements of TFK could be tallied for each study, this does not necessarily reflect the actual level of TFK possessed by each culture. Differences in depth of TFK reflected in the literature were also affected by factors such as: (1) whether traditional fire management was actively practiced or only historical at the time of the research; (2) the purpose and depth of the investigation, including the degree of the investigator's familiarity with fire; (3) whether the researcher was able to build upon a foundation of prior knowledge about TFK in the culture of interest; (4) how forthcoming the participants were in sharing detailed information (Hill et al. 1999); and (5) whether or not the investigators were able to observe traditional fire practitioners interacting with live fire.

The work by Garde et al. (2009) was especially rich for these reasons. First, it is focused on Aboriginal burning in Australia, where "more is known about Aboriginal fire usage compared with any other group of hunter-gatherer people on Earth" (Bowman et al. 2004:208). Fire has been used for landscape management by Aboriginal people in Australia far longer than in any other region (Jones 1969, Haynes 1991, Strang 1997), and its use has continued in some form to this day where it can be directly observed and explained as living knowledge. "These studies are the voices of the Aboriginal people themselves" (Garde et al. 2009:85), the people who are doing the burning. The TFK research from Australia contrasts with other studies, from North America for example, where indigenous cultures have been largely exterminated, much traditional knowledge has been lost, extant TFK is carefully guarded by indigenous people, and historical accounts are the primary sources of information available to outsiders. At the continental scale, the TFK systems of Europe appear to be the most endangered, with very few locations in which traditional fire management is still practiced (Seijo 2005). In Asia, the paucity of detailed TFK accounts contrasts with the known existence of community-based fire management programs (Moore et al. 2002) and with the high counts of fire detections in populated regions such as northern India, Southeast Asia, and eastern China (Giglio et al. 2006, Krawchuk and Moritz 2009). This suggests that the TFK of Asia is either not well studied or that it is underrepresented in Western scientific literature, or both.

\section{Three typologies for describing traditional fire knowledge systems}

The many elements of TFK and the ways in which they are combined produce so many permutations that the totality of TFK is difficult to grasp. Describing bodies of TFK as knowledge systems that include both social and ecological dimensions can help. Seijo and Gray (2012) propose a system of pre- and postindustrial anthropogenic fire regimes (PIAFRs and IAFRs), and I propose two more. The body of literature included in this paper fits all three ways of thinking, depending upon the analysis desired. Cross-referencing and layering these typologies can also be informative, and further examination will no doubt elucidate variations, combinations, gray areas, and all-together new typologies.

\section{Classification based on agro-ecological type}

The first typology revolves around the economic system of burning, or agro-ecological type. The 35 studies examined fell into four agro-ecological fire knowledge types: swidden, arborist, tame pasture, and open native vegetation. Although rooted in social-ecological systems, fire knowledge used for large-scale land use change, such as the deforestation of the United States during the 19th century (Wells 1968) or for deforestation of the Amazon today (Cochrane et al. 1999), does not meet any definition of TEK or TFK, and thus is not included.

In a generalized sense, swidden TFK is that incorporated into burning for slash and burn agriculture or for clearing small forest patches. Swidden fire knowledge involves some tree or shrub cutting prior to burning and the fire's purpose is for growing crops. Patch sizes are small, timing revolves around planting or removing harvest stubble, and fire effects of primary interest are increasing available sunlight, converting nutrients in standing biomass into available soil nutrients, and reducing noncrop species. Swidden fire cultures are or were typically located in forested sites, in preindustrial Europe, or in the humid tropics, for example.

Arborist fire knowledge systems are those in which traditional fire managers use fire to maintain trees either in groves or individually. Vegetation around or near trees is burned at times appropriate for clearing understory vegetation, controlling pests, stimulating fruit production, maintaining sacred sites, or other purposes. The TFK that the Soliga people of South India apply to managing "amla" (fruit of Phyllanthus spp.) is an example of this system (Rai et al. 2007, Setty et al. 2008). Another example is the fire knowledge systems used by Native American Indian tribes in California to tend grandmother oak trees and to manage acorn harvests (Anderson 2005; T. Nason, personal communication, 2011).

In tame pasture TFK systems, traditional fires are used to maintain forage for domestic livestock in delineated pastures. Fire knowledge can be applied in small, confined pastures having a monoculture of specific forage grasses or in wide 
ranging landscapes seeded to some degree with desirable forage species. In either case, the influence of planting or seeding vegetation to improve grazing is present. Fuel loads are typically low because of the combination of regular grazing and frequent burning. Patch sizes vary, and both fire timing and fire effects revolve around maximizing the availability and nutrient quality of forage to maximize animal products. Controlling pests such as snakes and ticks that affect livestock, as well as reducing the prevalence of shrubs and undesirable herbs that reduce pasture quality are common fire purposes in this system type. The TFK employed by agricultural producers of Mayan descent in southern Mexico (Huffman 2010) is an example. Tame pastoral systems are often combined with open native vegetation systems.

The fourth knowledge system in this typology is TFK incorporated into burning open native vegetation. In this system, traditional fire managers use fire in unconfined areas of expansive native vegetation. Among the four system types based on agro-ecology, traditional practitioners use fire for the widest variety of purposes in this type. Purposes include hunting, gathering, nomadic pastoralism, clearing travel routes, maintaining village sites, and many more (Stewart et al. 2002). Traditional fire knowledge tends to be complex and highly nuanced in this system, dialed into subtle variations in weather, plant and animal phenology, fuel changes, and variations in physical characteristics of the surrounding landscape. Pronounced wet and dry seasons are a common feature in the ecologies of many TFK systems revolving around open native vegetation. Common ecosystems are grasslands, savannas, and open forests, which have coexisted with anthropological burning for millennia (Bowman et al. 2009). Social-ecological fire systems developed by the Aboriginal people of Australia, the Native Americans and First Peoples of the United States and Canada, and the several tribes of the Serengeti Plains in Africa are well-studied examples of this type of TFK system.

\section{Classification based on preindustrial or postindustrial anthropogenic fire regime}

Seijo and Gray (2012) offer a typology of preindustrial anthropogenic fire regimes (PIAFRs) versus industrial anthropogenic fire regimes (IAFRs). All of the traditional fire systems included in this synthesis falls into the category of PIAFRs. Nonetheless, the pre- or postindustrial distinction is particularly helpful in understanding the trajectory of TFK in both the past and present. The case of Europe provides a classic example. As Europe industrialized and modernized, firedependent economies declined, burning was actively discouraged by policy of central governments, afforestation favored industrial forestry that required industrial fire exclusion, and TFK was largely lost (Pyne 1997, Seijo 2005). Today, the TFK of Europe survives in only small pockets, such as among insistent peasants in Northern Spain (Seijo 2005).
Even there it is used as a tool for social resistance as much as for maintaining livelihoods (Seijo 2005). Today, changes in agricultural economies and demographics in developing countries may lead to similar declines.

Classification based on viability status

A third typology I propose is based on the viability and stability of TFK's current status: robust, declining, rejuvenating, or historical. The robust category describes social-ecological fire systems that have persisted and continue to evolve over time, allowing for some changes in continuity but remaining essentially intact until today. In parts of Australia, the "firestick farming" culture is the most continuous and best studied example of this in the world (Jones 1969, Haynes 1991, Strang 1997, Bowman et al. 2004).

Declining fire systems are those in which TFK still exists within members of a given culture, but in which demographic, economic, political, land use, or other changes threaten its continued viability. Jardel-Peláez (personal communication, 2008) provided an example of what may become a declining TFK system in Mexico, near the protected area of La Reserva de la Biosfera Sierra de Manantlán. A land cooperative (ejido) in the vicinity has experienced such out-migration of its young people to the cities that now the community has only elderly residents living locally, who are getting too old to conduct the burning. Elders express concern that there are fewer and fewer fire-knowledgeable people available in the community when the burning needs to be done, and that there are no young people in residence to inherit the practice. If the demographic pattern of this community were repeated throughout the broader landscape for enough time without improvement, this would represent a declining TFK system.

Rejuvenating systems are those in which active efforts are underway to both recover or to share TFK and, because viable TFK is necessarily a knowledge system of praxis, efforts are also underway to expand the application of traditional practices in landscapes in which traditional fire management was once the norm. Several landscapes in the U.S. Fire Learning Network (USFLN) have rejuvenating TFK systems. A cooperative program of the U.S. Forest Service, the four fire agencies of the U.S. Department of Interior, and The Nature Conservancy, the USFLN supports multistakeholder, multiscalar efforts to restore fire-adapted social-ecological systems (Butler and Goldstein 2010). Thirteen Native American groups have engaged as partners in USFLN landscapes during the past ten years, with rejuvenating TFK being a direct or indirect result of expanded focus on restoration of landscapes formerly dominated by traditional fire systems. These participating groups are members of the Apache, Caddo, Crow, Esselen, Ho-Chunk, Karuk, Klamath, Paiute, Pueblo, Shoshone, Warm Springs, Washoe, and Yakama Tribes (U.S. Fire Learning Network, unpublished data). 
Historical TFK systems are those in which so much of TFK has been lost that what remains is largely historical, preserved in written, graphical, or anecdotal accounts. Active fire management is no longer practiced, and the knowledge system no longer continues to evolve. The TFK once used to manage the temperate ecosystems of central Europe (Pyne 1997) are now largely historical. The TFK of many Native American cultures of North America that were decimated during European settlement also fall into this category, although some are rejuvenating.

Somewhere among these four types of viability statuses are two other descriptors, "narrowed" and "interrupted." As a generalized example, most indigenous peoples in North America were forced from their ancestral lands, punished for speaking their native languages, and forbidden to use fire in open native vegetation. Many groups experienced declining TFK systems abruptly and for several generations. However, some tribes retained enough TFK so that, although they did not practice traditional burning continuously on the landscape, and although some of their expert practitioners passed away, they could later draw upon enough knowledge to engage in the rejuvenation process. Narrowed knowledge systems escape becoming purely historical. Finally, TFK systems that were once constrained but then are rejuvenated would, in retrospect, be classified as having been interrupted.

\section{Traditional fire knowledge topics for future research}

No matter the classification of the TFK system, it is clear that indigenous and other traditional practitioners in many places purposefully manipulate a number of variables to achieve specific goals. The striking degree to which the elements of TFK overlap in disparate social-ecological systems leads to several speculative propositions to be explored in future research. A first proposition is that there exists a universal set of basic TFK elements that indigenous fire cultures discern and manipulate. The idea is that to effectively maintain a social-ecological fire system over time, especially in a fire system of open expansive vegetation, practitioners using preindustrial methods need to be able to manipulate a standard suite of variables over multiple generations. Candidate variables to explore would be the elements most commonly tallied in this synthesis (Table 2).

A related proposition arises from the prevalence of accounts that demonstrate knowledge of interacting elements. To what extent, if any, must traditional fire practitioners manipulate some minimum combination of fire elements to operate TFK systems? Because the average number of elements recorded in the 35 studies was 21 , and because practitioners in both preand postindustrial contexts know that many of these variables influence one another in complex fire dynamics, then perhaps an interwoven bundle of knowledge is required, rather than just individual elements. Such a bundle would be needed for practicing traditional fire management, for transmitting it from generation to generation, and for sustaining a fire-dependent social-ecological system over long time periods. Understanding more about a potential group of necessary building blocks would be informative, especially for those cultures in the process of rejuvenating TFK systems.

Another proposition relates to how TFK systems evolve. Assuming that practitioners from different places have not been in contact with one another over the generations, has TFK that shares similar characteristics legitimately coevolved? Candidates for study would be TFK knowledge systems of similar agro-ecological types from similar climates on different continents. For example, have the swidden TFK systems in moist tropical forests in South America and Asia coevolved?

Although this synthesis provides ample evidence that many elements of TFK are common across social-ecological systems, the combinations of elements in each place, multiplied by the local manifestation of each element, result in many different local or regional pyrogeographies, as defined by Bowman and Murphy (2011). Individual pyrogeographies are not necessarily interchangeable from place to place, and blindly acting as if they are could be deleterious (Mayer 2002). E. Martinson (personal communication, 2011) suggests that some aspects of TFK may be endemic, and that individual pyrogeographies are to some extent a combination of universal and endemic fire knowledge.

This notion leads to a last suggestion for TFK research, which relates to the resilience of TFK systems under the influence of climate change. Some of the most common elements of TFK are predicted to shift with climate change, namely weather, vegetation, and animal behavior (Bachelet et al. 2001, Parmesan and Yohe 2003, Chen et al. 2011, Moritz et al. 2012). Given the multiple elements of fire knowledge and the specialized combinations that characterize the pyrogeographies of different localities, an important area of inquiry is the extent to which traditional fire managers can reorganize and reapply these elements to meet their needs as local social-ecological systems change. Will adapting traditional fire knowledge be ecologically and socially feasible? In what ways will TFK systems as a whole be resilient in the face of climate change and in what ways will they be vulnerable?

\section{Avoiding losses of traditional fire knowledge and traditional fire knowledge systems from pathological responses to climate change}

As the global climate changes, "disruptions to fire activity will threaten ecosystems and human well-being throughout the world" (Moritz et al. 2012:1). In places in which two conditions exist, i.e., increases in fire activity and variability are taking place and social-ecological systems are firedependent, wildfire disasters will become chronic. Broadly scattered fire escapes, voluminous greenhouse gas emissions, and unanticipated fire effects are likely to result from 
traditional practices that once provided substantive social and ecological benefits within elegant control. The large-scale fires of 1997-1998 in Mexico and Indonesia are exactly such cases (Rodríguez-Trejo and Pyne 1999, Page et al. 2002). Public institutions tend to react to natural disasters by adopting engineering and technological solutions that fail to resolve chronic environmental problems (Gunderson and Light 2006). In places in which TFK systems have declined and fire exclusion has become hegemonic, wildfires illicit a pronounced and well developed pathological response of fire command and control (Holling and Meffe 1996). Central governments outlaw burning or regulate the practice more tightly. Investments in firefighting labor, equipment, and technology increase, even when the cost is high and long term effectiveness is in doubt. Fire prevention campaigns step up attempts to convince even people who depend upon fire for survival to hunt, gather, herd, or farm in some other way.

At the same time, such responses in Spain, Madagascar, and Brazil have demonstrated, for as long as a century, that prohibition and sanctions for using fire in systems in which people depend upon it for utilitarian purposes is largely futile and often counterproductive (Kull 2002, Seijo 2009, Pivello 2011). In regions where fire activity is predicted to increase or become less predictable with climate change, traditional fire practitioners and central governments are poised to clash in fire-related crisis after crisis, a maladaptive cycle increasingly out of synch with desperately needed creative problem solving. The ability of social-ecological fire systems to function successfully in a hotter world will require proactive information sharing, inclusive collaboration, and a genuine interest in weaving together insights from multiple cosmologies. As in other kinds of natural resource management, cross-cultural problem solving about vegetation fires is complex and uncomfortable, but it can be done (Bohensky and Maru 2011, Mason et al. 2012). Northern Australia's West Arnhem Land Fire Abatement project is a striking example of success, in which TFK is not only being used to manage fire-adapted landscapes, but also to achieve social-ecological objectives in carbon cycling and reducing greenhouse gas emissions (Fitzsimons et al. 2012).

\section{CONCLUSION}

This synthesis of TFK illuminates the richness and complexity of TFK around the world and provides perspective on the global body of TFK for perhaps the first time. At the local and regional scales, the ways in which subsets of the 69 knowledge elements are expressed and combined produce many pyrogeographies of considerable nuance and sophistication. That two-thirds of the elements were recorded on four or more continents supports the original hypothesis that traditional fire practitioners all over the world use common elements of fire knowledge. Classifying TFK into knowledge systems such as the agro-ecological type, pre- or postindustrial regimes, or viability status helps to organize TFK and to highlight larger- scale topics for future research. These include whether or not TFK has coevolved, the extent to which some combination of TFK is universal and necessary to sustain traditional systems over time, and how resilient TFK systems are to climate change. The longevity of traditional fire knowledge and practice faces serious threats at precisely the time when climate change promises disruptions in fire activity that will be problematic for indigenous and nonindigenous societies alike. Not only is it urgent to further explore and document TFK, but the time has come to seriously engage traditional fire practitioners in solving problems of global significance.

Responses to this article can be read online at: http://www.ecologyandsociety.org/issues/responses. php/5843

\section{Acknowledgments:}

I gratefully acknowledge Philip N. Omi, Maria FernandezGimenez, Dante Arturo Rodríguez-Trejo, Kathleen Galvin, Monique Rocca, and Ronald L. Myers. Partial funding was provided by El Fundo Mexicano para la Conservación de Naturaleza, The Nature Conservancy, the US Fire Learning Network, and an anonymous donor. In-kind support was provided by the Universidad Autonoma de Chapingo and Colorado State University. Responsibility for any errors in the tally of fire elements is mine.

\section{LITERATURE CITED}

Anderson, M. K. 2005. Tending the wild: Native American knowledge and the management of California's natural resources. University of California Press, Berkeley, California, USA.

Bachelet, D., R. P. Neilson, J. M. Lenihan, and R. J. Drapek. 2001. Climate change effects on vegetation distribution and carbon budget in the United States. Ecosystems 4:164-185. http://dx.doi.org/10.1007/s10021-001-0002-7

Berkes, F. 2012. Sacred ecology: traditional ecological knowledge and resource management. Third edition. Routledge, Abingdon, UK and New York, New York, USA.

Bohensky, E. L., and Y. Maru. 2011. Indigenous knowledge, science, and resilience: what have we learned from a decade of international literature on "integration"? Ecology and Society 16(4): 6. http://dx.doi.org/10.5751/ES-04342-160406

Bowman, D. M. J. S., J. K. Balch, P. Artaxo, W. J. Bond, J. M. Carlson, M. A. Cochrane, C. M. D'Antonio, R. S. DeFries, J. C. Doyle, S. P. Harrison, F. H. Johnston, J. E. Keeley, M. A. Krawchuk, C. A. Kull, J. B. Marston, M. A. Moritz, I. C. Prentice, C. I. Roos, A. C. Scott, T. W. Swetnam, G. R. van 
der Werf, and S. J. Pyne. 2009. Fire in the Earth system. Science 324(5926):481-484. http://dx.doi.org/10.1126/ science. 1163886

Bowman, D. M. J. S., and B. P. Murphy. 2011. Australia - a model system for the development of pyrogeography. Fire Ecology 7(1):5-12. http://dx.doi.org/10.4996/fireecology.0701005

Bowman, D. M. J. S., A. Walsh, and L. D. Prior. 2004. Landscape analysis of Aboriginal fire management in Central Arnhem Land, north Australia. Journal of Biogeography 31:207-223. http://dx.doi.org/10.1046/j.0305-0270.2003.00997. $\underline{\mathrm{x}}$

Boyd, R., editor. 1999. Indians, fire, and the land in the Pacific Northwest. Oregon State University Press, Corvallis, Oregon, USA.

Butler, W.H., and B. E. Goldstein. 2010. The US Fire Learning Network: springing a rigidity trap through multiscalar collaborative networks. Ecology and Society 15(3): 21. [online] URL: www.ecologyandsociety.org/vol15/iss3/art21/

Cabrera-García, L. 2006. Linking social and ecological dynamics for bird conservation: protecting the endangered Sierra Madre Sparrow in Chichinautzin, Mexico. Dissertation. McGill University, Montreal, Quebec, Canada. [online] URL: http://digitool.Library.McGill.CA:80/R/-?func=dbin-jumpfull\&object id=102793\&silo library=GEN01

Cairns, M., and D. Garrity. 1999. Improving shifting cultivation in Southeast Asia by building on indigenous fallow management strategies. Agroforestry Systems 47(1-3):37-48. http://dx.doi.org/10.1023/A:1006248104991

Chen, I.-C., J. K. Hill, R. Ohlemüller, D. B. Roy, and C. D. Thomas. 2011. Rapid range shifts of species associated with high levels of climate warming. Science 333(6045):1024-1026. http://dx.doi.org/10.1126/science.1206432

Cochrane, M. A., A. Alencar, M. D. Schulze, C. M. Souza, D. C. Nepstad, P. Lefebvre, and E. A. Davidson. 1999. Positive feedbacks in the fire dynamic of closed canopy tropical forests. Science 284(5421):1832-1835. http://dx.doi.org/10.1126/ science.284.5421.1832

Comision Nacional Forestal de Mexico (CONAFOR). 2009. El programa de protección contra incendios forestales. Comision Nacional Forestal de Mexico, Jalisco, Mexico. [online] URL: http://www.conafor.gob.mx/portal/index.php/ transparencia-y-rendicion-de-cuentas/transparencia-focalizada/ programa-incendios-forestales

Countryman, C. M. 1966. The concept of fire environment. Fire Control Notes 27:8-10.

Fernandez-Gimenez, M. E. 2000. The role of Mongolian nomadic pastoralists' ecological knowledge in rangeland management. Ecological Applications 10(5):1318-1326.
http://dx.doi.org/10.1890/1051-0761(2000)010[1318:TROMNP] 2.0.CO;2

Fitzsimons, J., J. Russell-Smith, G. James, T. Vigilante, G. Lipsett-Moore, J. Morrison, and M. Looker. 2012. Insights into the biodiversity and social benchmarking components of the Northern Australian fire management and carbon abatement programmes. Ecological Management and Restoration 13(1):51-57. http://dx.doi.org/10.1111/ j.1442-8903.2011.00624.x

Food and Agriculture Organization of the United Nations (FAO) and Project FireFight South East Asia. 2003. Community-based fire management: case studies from China, The Gambia, Honduras, India, the Lao People's Democratic Republic and Turkey. RAP Publication 2003/08, Working Paper FFM/2. Food and Agriculture Organization of the United Nations, Regional Office for Asia and the Pacific, Bangkok, Thailand. [online] URL: http://www.fao.org/ DOCREP/006/AD348E/AD348E00.HTM

Garde, M., B. L. Nadjamerrek, M. Kolkkiwarra, J. Kalarriya, J. Djandjomerr, B. Birriyabirriya, R. Bilindja, M. Kubarkku, and P. Biless. 2009. The language of fire: seasonality, resources and landscape burning on the Arnhem Land Plateau. Pages 85-180 in J. Russell-Smith, P. Whitehead, and P. Cooke, editors. Culture, ecology and economy of fire management in North Australian savannas: rekindling the Wurrk tradition. CSIRO, Collingwood, Victoria, Australia.

Giglio, L., I. Csiszar, and C. O. Justice. 2006. Global distribution and seasonality of active fires as observed with the Terra and Aqua Moderate Resolution Imaging Spectroradiometer (MODIS) sensors. Journal of Geophysical Research 111(G2):G02016. http://dx.doi.org/10.1029/2005JG000142

González, R. J. 2001. Zapotec science: farming and food in the Northern Sierra of Oaxaca. University of Texas Press, Austin, Texas, USA.

Gunderson, L., and S. S. Light. 2006. Adaptive management and adaptive governance in the Everglades ecosystem. Policy Sciences 39(4):323-334. http://dx.doi.org/10.1007/s11077-006-9027-2

Haynes, C. D. 1991. Use and impact of fire. Pages 61-71 in C. D. Haynes, M. G. Ridpath, and M. A. J. Williams, editors. Monsoonal Australia: landscape, ecology and man in the northern lowlands. Balkema, Leiden, The Netherlands.

Hill, R., A. Baird, and D. Buchanan. 1999. Aborigines and fire in the wet tropics of Queensland, Australia: ecosystem management across cultures. Society and Natural Resources 12(3):205-223. http://dx.doi.org/10.1080/089419299279704

Holling, C. S., and G. K. Meffe. 1996. Command and control and the pathology of natural resource management. Conservation Biology 10(2):328-337. http://dx.doi.org/10.1046/ j.1523-1739.1996.10020328.x 
Huffman, M. R. 2010. Community-based fire management at La Sepultura Biosphere Reserve, Chiapas, Mexico. Dissertation. Colorado State University, Fort Collins, Colorado, USA. [online] URL: http://discovery.library. colostate.edu/Record/DigiTool111267

Jones, R. 1969. Fire-stick farming. Australian Natural History 169(September):224-228.

Jurvélius, M. 2004. Community-based fire managment in southern Africa. Unasylva 217(55):12-14. [online] URL: ftp:// ftp.fao.org/docrep/fao/007/y5507e/y5507e05.pdf

Krawchuk, M. A., and M. A. Moritz. 2009. Fire regimes of China: inference from statistical comparison with the United States. Global Ecology and Biogeography 18(5):626-639. http://dx.doi.org/10.1111/j.1466-8238.2009.00472.x

Kull, C. A. 2002. Madagascar aflame: landscape burning as peasant protest, resistance, or a resource management tool? Political Geography 21(7):927-953. http://dx.doi.org/10.1016/ S0962-6298(02)00054-9

Mason, L., G. White, G. Morishima, E. Alvarado, L. Andrew, F. Clark, M. Durglo, J. Durglo, J. Eneas, J. Erickson, M. Friedlander, K. Hamel, C. Hardy, T. Harwood, F. Haven, E. Isaac, L. James, R. Kenning, A. Leighton, P. Pierre, C. Raish, B. Shaw, S. Smallsalmon, V. Stearns, H. Teasley, M. Weingart, and S. Wilder. 2012. Listening and learning from traditional knowledge and western science: a dialogue on contemporary challenges of forest health and wildfire. Journal of Forestry 110(4):187-193. http://dx.doi.org/10.5849/ jof.11-006

Mayer, J. 2002. Learning across borders: community-based fire management - Kalimantan to California. Pages 16-26 in P. Moore, D. Ganz, C. Tan Lay, T. Enters, and P. B. Durst, editors. Communities in flames: proceedings of an international conference on community involvement in fire management. RAP Publication 2002/25. Food and Agriculture Organization of the United Nations and FireFight South East Asia, Bangkok, Thailand. [online] URL: http://www.fao.org/ docrep/005/AC798E/AC798E00.HTM

McDaniel, J., D. Kennard, and A. Fuentes. 2005. Smokey the tapir: traditional fire knowledge and fire prevention campaigns in lowland Bolivia. Society and Natural Resources 18 (10):921-931. http://dx.doi.org/10.1080/08941920500248921

Mistry, J., A. Berardi, V. Andrade, T. Krahô, P. Krahô, and O. Leonardos. 2005. Indigenous fire management in the cerrado of Brazil: the case of the Krahô of Tocantíns. Human Ecology 33(3):365-386. http://dx.doi.org/10.1007/s10745-005-4143-8

Moore, P., D. Ganz, L. C. Tan, T. Enters, and P. B. Durst. 2002. Communities in flames: proceedings of an international conference on community involvement in fire management. RAP Publication 2002/25, Food and Agriculture Organization of the United Nations and FireFight South East Asia, Bangkok, Thailand. [online] URL: http://www.fao.org/docrep/005/ AC798E/AC798E00.HTM

Moritz, M. A., M.-A. Parisien, E. Batllori, M. A. Krawchuk, J. Van Dorn, D. J. Ganz, and K. Hayhoe. 2012. Climate change and disruptions to global fire activity. Ecosphere 3(6):49. http://dx.doi.org/10.1890/ES11-00345.1

Oltremari, J. V., and R. G. Jackson. 2006. Conflicts, perceptions, and expectations of indigenous communities associated with natural areas in Chile. Natural Areas Journal 26(2):215-220. http://dx.doi.org/10.3375/0885-8608(2006) 26[215:CPAEOI]2.0.CO;2

Otterstrom, S. M. 2004. Fire in a neotropical dry forest: cultural uses and ecological effects. Dissertation. University of California Davis, Davis, California, USA. [online] URL: http://www.bio-nica.info/biblioteca/Otterstrom\% 202004FireAndEcologicalEffects.pdf

Page, S. E., F. Siegert, J. O. Rieley, H.-D. V. Boehm, A. Jaya, and S. Limin. 2002. The amount of carbon released from peat and forest fires in Indonesia during 1997. Nature 420 (6911):61-65. http://dx.doi.org/10.1038/nature01131

Parmesan, C., and G. Yohe. 2003. A globally coherent fingerprint of climate change impacts across natural systems. Nature 421(6918):37-42. http://dx.doi.org/10.1038/nature01286

Pimbert, M. P., and J. N. Pretty. 1995. Parks, people and professionals: putting 'participation' into protected area management. Discussion Paper Number 57, United Nations Research Institute for Social Development, International Institute for Environment and Development and World Wide Fund for Nature, Geneva, Switzerland. [online] URL: http:// www.ibcperu.org/doc/isis/6931.pdf

Pivello, V. R. 2011. The use of fire in the cerrado and Amazonian rainforests of Brazil: past and present. Fire Ecology 7(1):24-39. http://dx.doi.org/10.4996/fireecology.0701024

Pyne, S. J. 1997. Vestal fire: an environmental history, told through fire, of Europe and Europe's encounter with the world. University of Washington Press, Seattle, Washington, USA.

Rai, N. D., C. M. Gowda, and S. Setty. 2007. Taragu Benki: fire use by Soliga adivasis in Biligiri Rangaswamy Temple Wildlife Sanctuary, Karnataka. Pages 87-89 in R. Pai, A. J. Hiremath, and Umakant, editors. Rethinking forest fires: proceedings of the national workshop on forest fires. Ashoka Trust for Research in Ecology and the Environment, New Delhi, India. [online] URL: http://www.atree.org/sites/ default/files/Forest_Booklet_ver3.pdf

Rodgers, W. A. 1986. The role of fire in the management of wildlife habitats: a review. Indian Forester 112:845-857. [online] URL: http://www.indianforester.co.in/index.php/ indianforester/article/view/10004 
Rodríguez-Trejo, D., and S. J. Pyne. 1999. Mexican fires of 1998. International Forest Fire News 20:61-63. [online] URL: http://www.fire.uni-freiburg.de/iffn/country/mx/mx 3.htm

Seijo, F. 2005. The politics of fire: Spanish forest policy and ritual resistance in Galicia, Spain. Environmental Politics 14 (3):380-402. http://dx.doi.org/10.1080/09644010500087665

Seijo, F. 2009. Who framed the forest fire? State framing and peasant counter-framing of anthropogenic forest fires in Spain since 1940. Journal of Environmental Policy and Planning 11 (2):103-128. http://dx.doi.org/10.1080/15239080902732570

Seijo, F., and R. W. Gray. 2012. Pre-industrial anthropogenic fire regimes in transition: the case of Spain and its implications for fire governance in Mediterranean type biomes. Human Ecology Review 19(1):58-69.

Seijo, F., R. W. Gray, and S. Rideout-Hanzak. 2011. Special issue: 4th international fire congress: fire as a global process. Fire Ecology 7(1):1-4. http://dx.doi.org/10.4996/fireecology.0701001

Setty, R. S., K. Bawa, T. Ticktin, and C. M. Gowda. 2008. Evaluation of a participatory resource monitoring system for nontimber forest products: the case of Amla (Phyllanthus spp.) fruit harvest by Soligas in South India. Ecology and Society 13(2): 19. [online] URL: http://www.ecologyandsociety.org/ vol13/iss $2 / \operatorname{art} 19 /$

Stewart, O. C., H. T. Lewis, and K. Anderson. 2002. Forgotten fires: Native Americans and the transient wilderness. University of Oklahoma Press, Norman, Oklahoma, USA.

Strang, V. 1997. Uncommon ground: landscapes, values and the environment. Berg, London, UK.

Turner, N. J. 1999. Time to burn. Pages 185-218 in R. Boyd, editor. Indians, fire and the land in the Pacific Northwest. Oregon State University Press, Corvallis, Oregon, USA.

Vélez, R. 2005. La población rural en la prevención de incendios forestales. United Nations Food and Agriculture Organization, Rome, Italy.

Wells, R. W. 1968. Fire at Peshtigo. Wisconsin Tales and Trails, Madison, Wisconsin, USA.

Whitehead, P. J., D. M. J. S. Bowman, N. Preece, F. Fraser, and P. Cooke. 2003. Customary use of fire by indigenous peoples in northern Australia: its contemporary role in savanna management. International Journal of Wildland Fire 12 (4):415-425. http://dx.doi.org/10.1071/WF03027 
Appendix 1. Geographic location or scope, and vegetation types included in 35 studies of traditional fire knowledge on six continents, as described by each author. All references for the appendices are provided at the end of Appendix 2.

\begin{tabular}{|c|c|c|c|c|}
\hline Reference & Continent & Country & Geographic Location, Scope & Vegetation \\
\hline Anderson 2005 & North America & USA & California & prairie, oak woodland, riparian \\
\hline Butz 2009 & Africa & Tanzania & village of Engikareti, northern Tanzania & shortgrass savanna, scrub, savanna woodlands \\
\hline $\begin{array}{l}\text { Cabrera-Garcia and } \\
\text { Frias } 2004\end{array}$ & North America & Mexico & $\begin{array}{l}\text { Milpa Alta in Distrito Federal; San Juan } \\
\text { Tlacotenco in Morelos }\end{array}$ & grassland \\
\hline Eriksen 2007 & Africa & Zambia & $\begin{array}{l}\text { Kafinda Game Management Area and Kasanka } \\
\text { National Park }\end{array}$ & $\begin{array}{l}\text { miombo woodland, tallgrass savanna, seasonal } \\
\text { grassy wetlands }\end{array}$ \\
\hline Forbes and Koster 1976 & Europe & Greece & eastern Peloponnese, southern Argolid & forest, scrub-maquis \\
\hline Garde 2009 & Australia & Australia & $\begin{array}{l}\text { Arhnem Land Plateau, coastal central north } \\
\text { Arnhem Land, Kakadu National Park }\end{array}$ & $\begin{array}{l}\text { sandstone heath, savanna, Eucalypt and other forest, } \\
\text { woodland, open woodland, sclerophyllous } \\
\text { shrubland, hummock grassland, billabong edge, } \\
\text { floodplain. }\end{array}$ \\
\hline $\begin{array}{l}\text { Grove and Rackham } \\
2001\end{array}$ & Europe & $\begin{array}{l}\text { Italy, Greece, } \\
\text { France, Spain }\end{array}$ & $\begin{array}{l}\text { Crete, Ligurian Appenines, Sardinia, } \\
\text { Mediterranean Basin }\end{array}$ & alpine pastures, grassland, maquis \\
\hline Haynes 1985 & Australia & Australia & Maningrida, north central Arnhemland & $\begin{array}{l}\text { open forest, eucalypt woodland, floodplain } \\
\text { (freshwater wetland), closed forest, non-eucalypt } \\
\text { woodland, paperbark forest, mangrove }\end{array}$ \\
\hline Hill et al. 1999 & Australia & Australia & Wet Tropics of Queensland World Heritage Area & $\begin{array}{l}\text { rainforest, sclerophyll forest, open grassy forest, } \\
\text { scrub, crop land }\end{array}$ \\
\hline Hough 1993 & Africa & West Africa & $\begin{array}{l}\text { West Africa national parks complex; northern } \\
\text { Benin, southern Niger and south-eastern Burkina } \\
\text { Faso }\end{array}$ & savanna woodland \\
\hline Huffman 2010 & North America & Mexico & $\begin{array}{l}\text { ejidos of Corazón del Valle and Valle de Corzo, La } \\
\text { Sepultura Biosphere Reserve, Chiapas, southern } \\
\text { Mexico }\end{array}$ & tropical pine-oak forest, crop land \\
\hline Kull 2002 & Africa & Madagascar & $\begin{array}{l}\text { village between Anstirabe and Ambositra, highland } \\
\text { Madagascar }\end{array}$ & $\begin{array}{l}\text { crop land, grassland, pasture, tapia woodlands, } \\
\text { cleared forest, plantations }\end{array}$ \\
\hline Lake 2007 & North America & USA & $\begin{array}{l}\text { Klamath-Siskyou bioregion, Northwestern } \\
\text { California; Pacific Northwest }\end{array}$ & $\begin{array}{l}\text { riparian, oak woodland, prairie, mixed conifer, } \\
\text { hardwood, meadow, chaparral }\end{array}$ \\
\hline Laris 2002 & Africa & Mali & Koulikoro district, southern Mali & $\begin{array}{l}\text { savanna, patch mosaic of grasses, trees and shrubs, } \\
\text { fallow land, crop land }\end{array}$ \\
\hline $\begin{array}{l}\text { Lewis and Ferguson } \\
1988\end{array}$ & North America & $\begin{array}{l}\text { Canada and } \\
\text { USA (excludes } \\
\text { content from } \\
\text { Australia) }\end{array}$ & $\begin{array}{l}\text { Wood Buffalo National Park, Alberta; Northwest } \\
\text { California, Western Washington }\end{array}$ & $\begin{array}{l}\text { boreal forest, prairies, parklands, meadows, sloughs, } \\
\text { deadfall and windfall forests }\end{array}$ \\
\hline Liacos 1973 & Europe & Greece & Chalkidiki peninsula, Thesprotia County & coniferous forest, maquis, rangelands, crop land \\
\hline
\end{tabular}




\begin{tabular}{|c|c|c|c|c|}
\hline Masipiqueña et al. 2000 & Asia & Philippines & Northeast Luzon & $\begin{array}{l}\text { crop land, grassland, closed-canopy rainforest, } \\
\text { logged-over forest, swidden agricultural land, cogon } \\
\text { grass, reforestation sites }\end{array}$ \\
\hline Maxwell 2004 & Asia & Cambodia & $\begin{array}{l}\text { southern Ratanakiri Province, northeastern } \\
\text { Cambodia }\end{array}$ & tropical dry forests (monsoonal) \\
\hline Mbow 2000 & Africa & Senegal & $\begin{array}{l}\text { Tambacounda and Saint-Louis districts, central- } \\
\text { eastern Senegal }\end{array}$ & $\begin{array}{l}\text { crop land, tree shrub savanna, shrub savanna, } \\
\text { grassland }\end{array}$ \\
\hline McDaniel et al. 2005 & South America & Bolivia & Lomerio, southeastern Bolivian lowlands & $\begin{array}{l}\text { pampa (savanna), dry to sub-humid forest, swidden } \\
\text { agricultural land }\end{array}$ \\
\hline $\begin{array}{l}\text { Miller and Davidson- } \\
\text { Hunt } 2010\end{array}$ & North America & Canada & $\begin{array}{l}\text { Pikangikum First Nation, Whitefeather Forest, } \\
\text { Northwest Ontario }\end{array}$ & boreal forest \\
\hline Mistry et al. 2005 & South America & Brazil & $\begin{array}{l}\text { Krahô indigenous reserve, within municipalities } \\
\text { Goiatins and Itacajá, northeastern Tocantíns }\end{array}$ & $\begin{array}{l}\text { cerrado (including savanna, grassland, dense } \\
\text { woodland, evergreen forest, riparian forest, } \\
\text { marshland) }\end{array}$ \\
\hline Otterstrom 2004 & South America & Nicaragua & & \\
\hline Pivello 2011 & South America & Brazil & $\begin{array}{l}\text { Great Plateau of Central Brazil, Amazon } \\
\text { rainforests }\end{array}$ & cerrado and rainforests \\
\hline Pyne 1997 & Europe & $\begin{array}{l}\text { Twelve } \\
\text { European } \\
\text { Countries }\end{array}$ & $\begin{array}{l}\text { France, Germany, Spain, Portugal, Italy, Greece, } \\
\text { Sweden, Denmark, Finland, England, Scotland, } \\
\text { Ireland }\end{array}$ & $\begin{array}{l}\text { numerous, including forest, woodland, shrubland, } \\
\text { orchards, pasture and crop land }\end{array}$ \\
\hline Rai et al. 2007 & Asia & India & Biligiri Rangaswamy Temple Wildlife Sanctuary & forest \\
\hline Reina 1967 & South America & Guatemala & $\begin{array}{l}\text { Community of San José, Lake Petén Itzá, northern } \\
\text { Petén Department }\end{array}$ & milpa crop land \\
\hline Rodgers 1986 & Asia & India & India & forests, moist grasslands, swidden agriculture \\
\hline Russell-Smith 1997 & Australia & Australia & $\begin{array}{l}\text { middle reaches of South Alligator River, Kakadu } \\
\text { National Park, near-coastal western Arnhem Land }\end{array}$ & $\begin{array}{l}\text { freshwater floodplain, open herbaceous } \\
\text { sedgelands/grasslands, lagoon, swamp, jungle, } \\
\text { Eucalypt open forest/woodland, savanna over } \\
\text { grassy understorey, evergreen monsoon forests }\end{array}$ \\
\hline Setty et al. 2008 & Asia & India & $\begin{array}{l}\text { Biligiri Rangaswamy Temple Wildlife Sanctuary, } \\
\text { southeast Chamarajanagara district, Karnataka }\end{array}$ & $\begin{array}{l}\text { dry deciduous forest, scrub jungle, evergreen forest, } \\
\text { savanna, shola }\end{array}$ \\
\hline Stewart 2002 & North America & USA & numerous locations across the US & numerous across the US \\
\hline Therik 2000 & Asia & $\begin{array}{l}\text { East Timor and } \\
\text { Indonesia }\end{array}$ & Island of Timor & crop land \\
\hline Turner 1999 & North America & Canada, USA & British Columbia, Alberta, Montana & $\begin{array}{l}\text { prairie,meadows, oak savanna, forests, berry } \\
\text { patches, vegetation in multiple biogeoclimatic zones }\end{array}$ \\
\hline Vélez 2005 & Europe & Spain & Spain, Mediterranean Basin, Europe & crop land, pasture, abandoned farmland \\
\hline Yibaruk et al. 2001 & Australia & Australia & $\begin{array}{l}\text { Dukaladjarranj clan estate, upper Cadel River, } \\
\text { north-central Arnhem Land, Kakadu National Park, } \\
\text { northern Australia }\end{array}$ & $\begin{array}{l}\text { savanna woodland, rainforest, floodplain, hummock } \\
\text { grassland, Eucalyptus and Melaleuca forest }\end{array}$ \\
\hline
\end{tabular}


APPENDIX 2. Elements of traditional fire knowledge recorded in each of 35 studies, organized by continent.

Table A.1. Elements of traditional fire knowledge recorded in studies from Africa $(n=6)$.

\begin{tabular}{|c|c|c|c|c|c|c|c|c|}
\hline Elements of Traditional Fire Knowledge $\backslash$ Country & Kull 2002 & $\begin{array}{l}\text { Butz } \\
2009\end{array}$ & $\begin{array}{c}\text { Mbow } \\
2000\end{array}$ & $\begin{array}{c}\text { Eriksen } \\
2007\end{array}$ & $\begin{array}{l}\text { Laris } \\
2002\end{array}$ & $\begin{array}{c}\text { Hough } \\
1993\end{array}$ & Africa C & $\begin{array}{l}\text { nposite } \\
\text { Number } \\
\text { of studies } \\
\text { recording } \\
\text { each } \\
\text { element }\end{array}$ \\
\hline \multicolumn{9}{|l|}{ Geology, Topography, Soil } \\
\hline Soil type, moisture & & & $\mathrm{X}$ & & $\mathrm{X}$ & & $\mathrm{X}$ & 2 \\
\hline Slope & $\mathrm{X}$ & & & & & & $\mathrm{X}$ & 1 \\
\hline \multicolumn{9}{|l|}{ Geologic substrate, landform } \\
\hline \multicolumn{9}{|l|}{ Elevation } \\
\hline Aspect & $\mathrm{X}$ & & & & & & $\mathrm{X}$ & 1 \\
\hline Soil temperature, frozen or thawed & $\mathrm{X}$ & & & & & & $\mathrm{X}$ & 1 \\
\hline \multicolumn{9}{|l|}{ Vegetation, Fuels } \\
\hline Moisture of live or dead fuels & $\mathrm{X}$ & $\mathrm{X}$ & $\mathrm{X}$ & $\mathrm{X}$ & $\mathrm{X}$ & & $\mathrm{X}$ & 5 \\
\hline Plant or animal phenology & $\mathrm{X}$ & $\mathrm{X}$ & $\mathrm{X}$ & & $\mathrm{X}$ & & $\mathrm{X}$ & 4 \\
\hline Fuel composition, species & & $\mathrm{X}$ & & & $\mathrm{X}$ & & $\mathrm{X}$ & 2 \\
\hline Fuel load & & $\mathrm{X}$ & & $\mathrm{X}$ & & & $\mathrm{X}$ & 2 \\
\hline Fuel or vegetation structure, arrangement, continuity, height & & & $\mathrm{X}$ & & & & $\mathrm{X}$ & 1 \\
\hline Fuel consumption: degree, speed, patchiness & $\mathrm{X}$ & & & & & & $\mathrm{X}$ & 1 \\
\hline Fuel diameter or size (e.g., logs vs. grass) & $\mathrm{X}$ & & & & & & $\mathrm{X}$ & 1 \\
\hline Vegetation type & & & $\mathrm{X}$ & & & & $\mathrm{X}$ & 1 \\
\hline
\end{tabular}


Season of the year

Onset or end of rainy season, dry season, timing of rain

Wind speed, force

Wind direction, source

Temperature

Humidity of air, day

Water level, stream flow, river cycle

Quantity of rain

Snow or ice location, condition (including melting or

breakup)

Lightning

Phase of moon

Sun's force and position in sky

Clouds

\section{Fire Behavior}

Fire intensity, heat output (hot or cool fire)

Frequency, return interval, time since fire

Fire size, area, aerial extent

Fire type (surface, ground, canopy)

Backing, heading fire

Direction of fire spread (including landmarks)

Flame height

Rate of spread

Natural extinguishment

Residence time

Evenness, smoothness

Spotting, sparks, embers carried aloft

\section{Fire Operations}

Fire control

Firebreaks, barriers

Time of day

Landscape pattern, patch size
$\mathrm{X}$

$\mathrm{X}$

$\mathrm{X}$

$\mathrm{X}$

$\mathrm{X}$

$\mathrm{X}$

$\mathrm{X}$

$\begin{array}{ll}\mathrm{X} & 6 \\ \mathrm{X} & 3 \\ \mathrm{X} & 3 \\ \mathrm{X} & 1 \\ \mathrm{X} & 2 \\ \mathrm{X} & 2\end{array}$

$\mathrm{X}$

1

\begin{tabular}{|c|c|c|c|c|c|}
\hline$X$ & \multirow[t]{7}{*}{$X$} & $\mathrm{X}$ & $X$ & $X$ & 5 \\
\hline$X$ & & & & $X$ & 2 \\
\hline \multirow[t]{5}{*}{$X$} & & & & $X$ & 1 \\
\hline & & & & $\mathrm{X}$ & 1 \\
\hline & & \multirow[t]{3}{*}{$X$} & & $X$ & 2 \\
\hline & & & & $\mathrm{X}$ & 1 \\
\hline & & & & $X$ & 1 \\
\hline$X$ & $X$ & $X$ & & $\mathrm{X}$ & 4 \\
\hline$X$ & & $\mathrm{X}$ & & $\mathrm{X}$ & 3 \\
\hline$X$ & & & & $X$ & 2 \\
\hline$X$ & & & & $X$ & 3 \\
\hline
\end{tabular}


Tools for preparation, ignition, control

$\mathrm{X}$

Crew size, use of neighbors

$\mathrm{X}$

Ignition pattern

Spatio-temporal sequence of fires, including for prevention

Danger, risk, destructive potential

Fire placement

\begin{tabular}{|c|c|c|c|c|}
\hline & \multirow[b]{4}{*}{$X$} & & $X$ & 1 \\
\hline & & & $X$ & 2 \\
\hline & & & $X$ & 1 \\
\hline & & & $X$ & 2 \\
\hline & \multirow{2}{*}{\multicolumn{2}{|c|}{$\mathrm{X}$}} & $X$ & 2 \\
\hline & & & $X$ & 1 \\
\hline$X$ & $X$ & $X$ & $X$ & 5 \\
\hline \multirow[t]{2}{*}{$X$} & $X$ & $X$ & $X$ & 6 \\
\hline & $X$ & & $X$ & 4 \\
\hline \multirow[t]{2}{*}{$X$} & & & $X$ & 2 \\
\hline & & & $X$ & 1 \\
\hline
\end{tabular}

Planning, monitoring conditions prior to burning

Site preparation

Fire duration

Special clothing

\section{Fire Effects}

Fire effects on vegetation

Fire effects on animals

Consequences of not burning

Fire effects on soil

$\begin{array}{ll}X & \\ X & X \\ X & X \\ X\end{array}$

$\mathrm{X}$

X

Scorch height, bark char, smoked leaves

Fire effects on watershed, water delivery

$x$

Burning illegal or regulated by central government

Gender roles in fire management

Land stewardship, care, cleaning up country, controlling

space

$X$
$X$
$X$
$X$

Burning regulated internally by community

Fire as tool in social resistance, protest, local conflict

$\mathrm{X}$

X

$\mathrm{X}$

$\mathrm{X}$

$\mathrm{X}$

5

Authority, decision to burn

$\mathrm{X}$

37

21

14

12

14

8

47 
Table A.2. Elements of traditional fire knowledge recorded in studies from Asia ( $\mathrm{n}=6)$.

\begin{tabular}{|c|c|c|c|c|c|c|c|c|}
\hline Elements of Traditional Fire Knowledge $\backslash$ Country & $\begin{array}{c}\text { Therik } \\
2000 \\
\\
\text { East } \\
\text { Timor } \\
\text { and } \\
\text { Indonesia }\end{array}$ & $\begin{array}{l}\text { Masipiqueña } \\
\text { et al. } 2000\end{array}$ & $\begin{array}{c}\text { Rai et al. } \\
2007\end{array}$ & $\begin{array}{l}\text { Setty et al. } \\
2008\end{array}$ & $\begin{array}{l}\text { Maxwell } \\
2004\end{array}$ & $\begin{array}{c}\text { Rodgers } \\
1986\end{array}$ & Asia Cc & $\begin{array}{l}\text { nposite } \\
\text { Number of } \\
\text { studies } \\
\text { recording } \\
\text { each } \\
\text { element } \\
\end{array}$ \\
\hline \multicolumn{9}{|l|}{ Geology, Topography, Soil } \\
\hline Soil type, moisture & & $\mathrm{X}$ & & & & & $\mathrm{X}$ & 1 \\
\hline Slope & $\mathrm{X}$ & & & & & & $\mathrm{X}$ & 1 \\
\hline Geologic substrate, landform & & $\mathrm{X}$ & & & & & $\mathrm{X}$ & 1 \\
\hline \multicolumn{9}{|l|}{ Elevation } \\
\hline \multicolumn{9}{|l|}{ Aspect } \\
\hline \multicolumn{9}{|l|}{ Soil temperature, frozen or thawed } \\
\hline \multicolumn{9}{|l|}{ Vegetation, Fuels } \\
\hline Moisture of live or dead fuels & $X$ & & & & & & $\mathrm{X}$ & 1 \\
\hline Plant or animal phenology & $\mathrm{X}$ & $\mathrm{X}$ & & & & & $\mathrm{X}$ & 2 \\
\hline Fuel composition, species & $\mathrm{X}$ & & & $\mathrm{X}$ & & & $\mathrm{X}$ & 2 \\
\hline Fuel load & $\mathrm{X}$ & & $\mathrm{X}$ & & & & $\mathrm{X}$ & 2 \\
\hline Fuel or vegetation structure, arrangement, continuity, height & $\mathrm{X}$ & & & $\mathrm{X}$ & $\mathrm{X}$ & & $\mathrm{X}$ & 3 \\
\hline \multicolumn{9}{|l|}{ Fuel consumption: degree, speed, patchiness } \\
\hline Fuel diameter or size (e.g., logs vs. grass) & $\mathrm{X}$ & & & & & & $\mathrm{X}$ & 1 \\
\hline Vegetation type & & $\mathrm{X}$ & $\mathrm{X}$ & & & & $\mathrm{X}$ & 2 \\
\hline \multicolumn{9}{|l|}{ Weather } \\
\hline Season of the year & & $\mathrm{X}$ & $\mathrm{X}$ & & $\mathrm{X}$ & $\mathrm{X}$ & $\mathrm{X}$ & 4 \\
\hline Onset or end of rainy season, dry season, timing of rain & $\mathrm{X}$ & $\mathrm{X}$ & $\mathrm{X}$ & & & & $\mathrm{X}$ & 3 \\
\hline
\end{tabular}


Wind speed, force

Wind direction, source

Temperature

Humidity of air, day

Water level, stream flow, river cycle

Quantity of rain

Snow or ice location, condition (including melting or

breakup)

Lightning

Phase of moon

Sun's force and position in sky

\section{Clouds}

\section{Fire Behavior}

Fire intensity, heat output (hot or cool fire)

Frequency, return interval, time since fire

X

Fire size, area, aerial extent

Fire type (surface, ground, canopy)

Backing, heading fire

Direction of fire spread (including landmarks)

Flame height

Rate of spread

Natural extinguishment

Residence time

Evenness, smoothness

Spotting, sparks, embers carried aloft $\mathrm{X}$

\section{$\mathrm{X}$}

$\mathrm{X}$

\section{Fire Operations}

Fire control

Firebreaks, barriers

Time of day

Landscape pattern, patch size

Tools for preparation, ignition, control

Crew size, use of neighbors

\begin{tabular}{|c|c|c|c|c|c|c|c|}
\hline & $X$ & $X$ & $X$ & & & $X$ & 3 \\
\hline & & & $X$ & $\mathrm{X}$ & $X$ & $X$ & 3 \\
\hline & & & $X$ & & & $X$ & 1 \\
\hline $\mathrm{X}$ & & & & & & $X$ & 1 \\
\hline$X$ & & & & & & $X$ & 1 \\
\hline$X$ & & & & & & $X$ & 1 \\
\hline & $X$ & & $X$ & & & $X$ & 2 \\
\hline $\mathrm{X}$ & & & & & & $X$ & 1 \\
\hline$X$ & & & & & & $X$ & 1 \\
\hline & $X$ & & & & & $X$ & 1 \\
\hline & $X$ & & & & & $X$ & 1 \\
\hline
\end{tabular}


Planning, monitoring conditions prior to burning

Site preparation

Fire duration

Special clothing

\section{Fire Effects}

Fire effects on vegetation

Fire effects on animals

Consequences of not burning

Fire effects on soil

\section{$\mathrm{X}$}

$\begin{array}{ll}X & X \\ X & X \\ & X\end{array}$

$\mathrm{X}$
$\mathrm{X}$
$\mathrm{X}$

$\mathrm{X}$

$\begin{array}{ll}\mathrm{X} & \mathrm{X} \\ & \mathrm{X} \\ \mathrm{X} & \end{array}$

$\mathrm{X}$

Smoke effects, smoke color, smoke column characteristics

Scorch height, bark char, smoked leaves

Fire effects on watershed, water delivery

\section{Fire Governance, Other Social Factors}

Burning illegal or regulated by central government

Gender roles in fire management

Land stewardship, care, cleaning up country, controlling space

Knowledge transmission

Burning regulated internally by community

Fire as tool in social resistance, protest, local conflict

Authority, decision to burn

Age of participants

Prohibited areas (customary, sacred, community safety)

Number of elements recorded X

$\mathrm{X}$

$\mathrm{X}$

$\mathrm{X}$

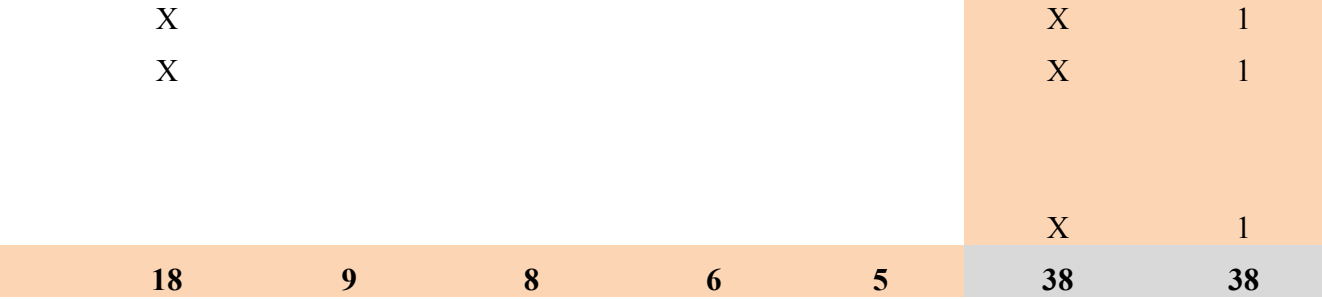


Table A.3. Elements of traditional fire knowledge recorded in studies from Australia $(n=5)$.

\begin{tabular}{|c|c|c|c|c|c|c|c|}
\hline Elements of Traditional Fire Knowledge $\backslash$ Country & $\begin{array}{l}\text { Garde } \\
2009\end{array}$ & Haynes 1985 & $\begin{array}{l}\text { Hill et al. } \\
1999\end{array}$ & $\begin{array}{c}\text { Russell- } \\
\text { Smith } \\
1997\end{array}$ & $\begin{array}{l}\text { Yibaruk } \\
\text { et al. } \\
2001\end{array}$ & Australia & $\begin{array}{l}\text { mposite } \\
\text { Number } \\
\text { of studies } \\
\text { recording } \\
\text { each } \\
\text { element }\end{array}$ \\
\hline \multicolumn{8}{|l|}{ Geology, Topography, Soil } \\
\hline Soil type, moisture & $\mathrm{X}$ & & & $\mathrm{X}$ & & $\mathrm{X}$ & 2 \\
\hline Slope & $\mathrm{X}$ & & & & & $\mathrm{X}$ & 1 \\
\hline Geologic substrate, landform & $\mathrm{X}$ & & $\mathrm{X}$ & $\mathrm{X}$ & & $\mathrm{X}$ & 3 \\
\hline Elevation & $\mathrm{X}$ & & & & $\mathrm{X}$ & $\mathrm{X}$ & 2 \\
\hline \multicolumn{8}{|l|}{ Aspect } \\
\hline \multicolumn{8}{|l|}{ Soil temperature, frozen or thawed } \\
\hline \multicolumn{8}{|l|}{ Vegetation, Fuels } \\
\hline Moisture of live or dead fuels & $\mathrm{X}$ & & $\mathrm{X}$ & $\mathrm{X}$ & $\mathrm{X}$ & $\mathrm{X}$ & 4 \\
\hline Plant or animal phenology & $\mathrm{X}$ & $\mathrm{X}$ & & $\mathrm{X}$ & $\mathrm{X}$ & $\mathrm{X}$ & 4 \\
\hline Fuel composition, species & $\mathrm{X}$ & $\mathrm{X}$ & $\mathrm{X}$ & $X$ & & $\mathrm{X}$ & 4 \\
\hline Fuel load & $\mathrm{X}$ & & $\mathrm{X}$ & $\mathrm{X}$ & $\mathrm{X}$ & $\mathrm{X}$ & 4 \\
\hline Fuel or vegetation structure, arrangement, continuity, height & $\mathrm{X}$ & & $\mathrm{X}$ & & & $\mathrm{X}$ & 2 \\
\hline Fuel consumption: degree, speed, patchiness & $\mathrm{X}$ & $\mathrm{X}$ & & & & $\mathrm{X}$ & 2 \\
\hline \multicolumn{8}{|l|}{ Fuel diameter or size (e.g., logs vs. grass) } \\
\hline Vegetation type & & $\mathrm{X}$ & & & & $\mathrm{X}$ & 1 \\
\hline \multicolumn{8}{|l|}{ Weather } \\
\hline Season of the year & $\mathrm{X}$ & $\mathrm{X}$ & $\mathrm{X}$ & $\mathrm{X}$ & $\mathrm{X}$ & $\mathrm{X}$ & 5 \\
\hline Onset or end of rainy season, dry season, timing of rain & $\mathrm{X}$ & $\mathrm{X}$ & & & $\mathrm{X}$ & $\mathrm{X}$ & 3 \\
\hline
\end{tabular}


Water level, stream flow, river cycle

Quantity of rain

Snow or ice location, condition (including melting or breakup)

Lightning

Phase of moon

Sun's force and position in sky

\section{Clouds}

\section{Fire Behavior}

Fire intensity, heat output (hot or cool fire)

Frequency, return interval, time since fire

Fire size, area, aerial extent

Fire type (surface, ground, canopy)

Backing, heading fire

Direction of fire spread (including landmarks)

Flame height

Rate of spread

Natural extinguishment

Residence time

Evenness, smoothness

Spotting, sparks, embers carried aloft

\begin{tabular}{|c|c|c|c|c|c|c|c|}
\hline \multicolumn{8}{|l|}{ Fire Operations } \\
\hline Fire control & $\mathrm{X}$ & $\mathrm{X}$ & $\mathrm{X}$ & $\mathrm{X}$ & $\mathrm{X}$ & $\mathrm{X}$ & 5 \\
\hline Firebreaks, barriers & $\mathrm{X}$ & $\mathrm{X}$ & $\mathrm{X}$ & $\mathrm{X}$ & & $\mathrm{X}$ & 4 \\
\hline Time of day & $\mathrm{X}$ & $\mathrm{X}$ & & $\mathrm{X}$ & & $\mathrm{X}$ & 3 \\
\hline Landscape pattern, patch size & $\mathrm{X}$ & $\mathrm{X}$ & $\mathrm{X}$ & $\mathrm{X}$ & $\mathrm{X}$ & $\mathrm{X}$ & 5 \\
\hline Tools for preparation, ignition, control & $\mathrm{X}$ & $\mathrm{X}$ & $\mathrm{X}$ & & & $\mathrm{X}$ & 3 \\
\hline Crew size, use of neighbors & $\mathrm{X}$ & & $\mathrm{X}$ & & & $\mathrm{X}$ & 2 \\
\hline
\end{tabular}


Spatio-temporal sequence of fires, including for prevention

Danger, risk, destructive potential

$\begin{array}{ll}X & X \\ X & X\end{array}$

Fire placement

Planning, monitoring conditions prior to burning

Site preparation

Fire duration

Special clothing

\section{Fire Effects}

Fire effects on vegetation

Fire effects on animals

Consequences of not burning

Fire effects on soil

$\begin{array}{lllllll}X & X & X & X & X & X & 5 \\ X & X & X & X & X & X & 5 \\ X & X & X & X & X & 4 \\ X & & & & & X & 1\end{array}$

Smoke effects, smoke color, smoke column characteristics

Scorch height, bark char, smoked leaves

Fire effects on watershed, water delivery

\section{Fire Governance, Other Social Factors}

Burning illegal or regulated by central government

Gender roles in fire management

X space

Knowledge transmission

Burning regulated internally by community

Fire as tool in social resistance, protest, local conflict

Authority, decision to burn

Age of participants

Prohibited areas (customary, sacred, community safety)

Number of elements recorded
X

$\mathrm{X}$

X

$\mathrm{X} \quad \mathrm{X}$

X $\quad X$

$\mathrm{X} \quad \mathrm{X}$

$X$
$X$

$\mathrm{X}$

26

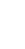

X

$\mathrm{X}$

$\mathrm{X}$

$\mathrm{X}$

X

X 2

\begin{tabular}{cccccc} 
& & & & & \\
& & & & $X$ & 2 \\
& & & & $X$ & 1 \\
& & & & $X$ & 1 \\
4 & & & & 54 & 54 \\
\hline
\end{tabular}


Table A.4. Elements of traditional fire knowledge recorded in studies from Europe ( $n=5)$. Elements tallied from Pyne (1997) included specific accounts from eight countries: Finland, France, Germany, Greece, Italy, Poland, Spain and Sweden.

\begin{tabular}{|c|c|c|c|c|c|c|c|}
\hline Elements of Traditional Fire Knowledge $\backslash$ Country & $\begin{array}{c}\text { Pyne } 1997 \\
\text { Eight } \\
\text { European } \\
\text { Countries } \\
\end{array}$ & $\begin{array}{l}\text { Grove and } \\
\text { Rackham } \\
2001 \\
\text { Mediterranean } \\
\text { Basin: Italy, } \\
\text { Greece, } \\
\text { France, Spain }\end{array}$ & $\begin{array}{c}\text { Vélez } 2005 \\
\text { Various: Spain, } \\
\text { Mediterranean } \\
\text { Basin, Europe }\end{array}$ & $\begin{array}{c}\text { Forbes and } \\
\text { Koster } 1976\end{array}$ & Liacos 1973 & Europe C & $\begin{array}{l}\text { nposite } \\
\text { Number } \\
\text { of studies } \\
\text { recording } \\
\text { each } \\
\text { element }\end{array}$ \\
\hline \multicolumn{8}{|l|}{ Geology, Topography, Soil } \\
\hline Soil type, moisture & $\mathrm{X}$ & & & & & $\mathrm{X}$ & 1 \\
\hline Slope & $\mathrm{X}$ & & & $\mathrm{X}$ & & $\mathrm{X}$ & 2 \\
\hline \multicolumn{8}{|l|}{ Geologic substrate, landform } \\
\hline \multicolumn{8}{|l|}{ Elevation } \\
\hline \multicolumn{8}{|l|}{ Aspect } \\
\hline \multicolumn{8}{|l|}{ Soil temperature, frozen or thawed } \\
\hline \multicolumn{8}{|l|}{ Vegetation, Fuels } \\
\hline Moisture of live or dead fuels & $\mathrm{X}$ & & & & & $X$ & 1 \\
\hline \multicolumn{8}{|l|}{ Plant or animal phenology } \\
\hline Fuel composition, species & $\mathrm{X}$ & & & & & $\mathrm{X}$ & 1 \\
\hline Fuel load & $\mathrm{X}$ & & & & & $X$ & 1 \\
\hline Fuel or vegetation structure, arrangement, continuity, height & $\mathrm{X}$ & & & & & $X$ & 1 \\
\hline Fuel consumption: degree, speed, patchiness & $X$ & & & & & $\mathrm{X}$ & 1 \\
\hline Fuel diameter or size (e.g., logs vs. grass) & $\mathrm{X}$ & & & & & $X$ & 1 \\
\hline \multicolumn{8}{|l|}{ Vegetation type } \\
\hline \multicolumn{8}{|l|}{ Weather } \\
\hline Season of the year & $\mathrm{X}$ & $\mathrm{X}$ & $\mathrm{X}$ & & $\mathrm{X}$ & $\mathrm{X}$ & 4 \\
\hline Onset or end of rainy season, dry season, timing of rain & $\mathrm{X}$ & $\mathrm{X}$ & & & & $\mathrm{X}$ & 2 \\
\hline Wind speed, force & $\mathrm{X}$ & & & & & $X$ & 1 \\
\hline Wind direction, source & $\mathrm{X}$ & & & & & $\mathrm{X}$ & 1 \\
\hline
\end{tabular}


Humidity of air, day

Water level, stream flow, river cycle

Quantity of rain

Snow or ice location, condition (including melting or

breakup)

Lightning

Phase of moon

Sun's force and position in sky

Clouds

\section{Fire Behavior}

Fire intensity, heat output (hot or cool fire)

Frequency, return interval, time since fire

Fire size, area, aerial extent

Fire type (surface, ground, canopy)

Backing, heading fire

Direction of fire spread (including landmarks)

Flame height

Rate of spread

Natural extinguishment

Residence time

Evenness, smoothness

Spotting, sparks, embers carried aloft

\section{Fire Operations}

\section{Fire control}

Firebreaks, barriers

Time of day

Landscape pattern, patch size

Tools for preparation, ignition, control

Crew size, use of neighbors

X

$\mathrm{X}$

$\mathrm{X}$

$\mathrm{X}$

$\begin{array}{ll}\mathrm{X} & 2 \\ \mathrm{X} & 1 \\ \mathrm{X} & 2 \\ \mathrm{X} & 1 \\ \mathrm{X} & 1 \\ \mathrm{X} & 2 \\ \mathrm{X} & 1 \\ \mathrm{X} & 1\end{array}$


Danger, risk, destructive potential

Fire placement

Planning, monitoring conditions prior to burning

Site preparation $\quad \mathrm{X}$

Fire duration $\quad \mathrm{X}$

Special clothing $\quad \mathrm{X}$

Fire Effects

Fire effects on vegetation

$\mathrm{X}$

Fire effects on animals

Consequences of not burning

Fire effects on soil

X $\quad \mathrm{X}$

X

X

Smoke effects, smoke color, smoke column characteristics

Scorch height, bark char, smoked leaves

Fire effects on watershed, water delivery

\section{Fire Governance, Other Social Factors}

Burning illegal or regulated by central government

Gender roles in fire managemen

Land stewardship, care, cleaning up country, controlling space

Knowledge transmission

Burning regulated internally by community

Fire as tool in social resistance, protest, local conflict

Authority, decision to burn

Age of participants

Prohibited areas (customary, sacred, community safety) 
Table A.5. Elements of traditional fire knowledge recorded in studies from North America $(n=8)$.

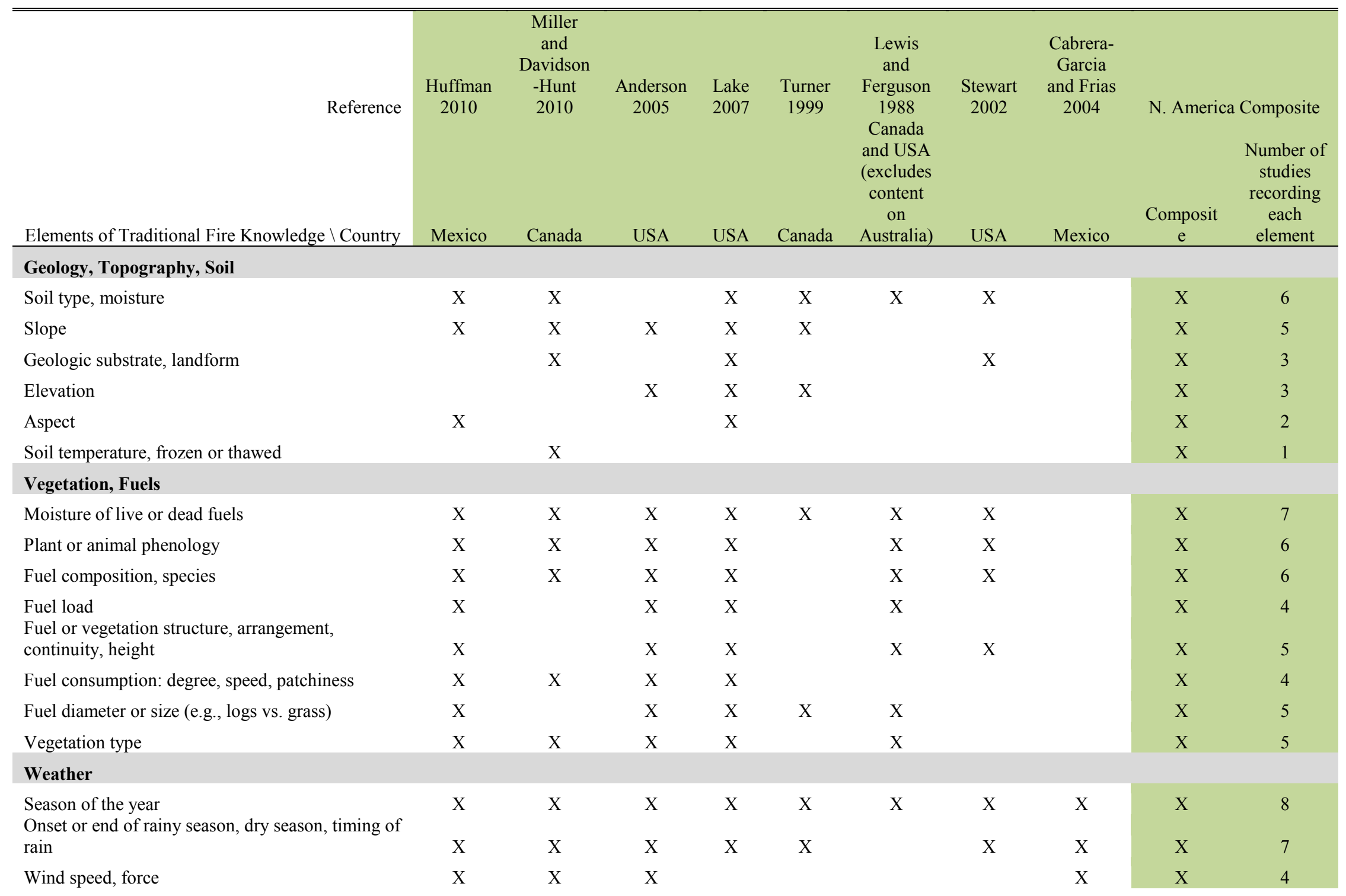


Wind direction, source

Temperature

Humidity of air, day

Water level, stream flow, river cycle

Quantity of rain

Snow or ice location, condition (including melting or breakup)

Lightning

Phase of moon

Sun's force and position in sky Clouds

\section{Fire Behavior}

Fire intensity, heat output (hot or cool fire)

Frequency, return interval, time since fire

Fire size, area, aerial extent

Fire type (surface, ground, canopy)

Backing, heading fire

Direction of fire spread (including landmarks)

Flame height

Rate of spread

Natural extinguishment

Residence time

Evenness, smoothness

Spotting, sparks, embers carried aloft

\section{Fire Operations}

Fire control

Firebreaks, barriers

Time of day

Landscape pattern, patch size

Tools for preparation, ignition, control

Crew size, use of neighbors

Ignition pattern

$\begin{array}{lllllll}X & X & X & X & X & & \\ X & X & & X & & & \\ X & & & & & & \\ & X & & X & & & \\ X & & & X & & \\ & X & X & X & X & X & X \\ & X & & X & & X & \end{array}$

X

$\mathrm{X} \quad \mathrm{X} \quad \mathrm{X}$

$\mathrm{X}-\mathrm{X} \quad \mathrm{X} \quad \mathrm{X}-\mathrm{X}$

$\mathrm{X} \quad \mathrm{X}$

$\mathrm{X}$

$\mathrm{X}$

$\mathrm{X}$

$\mathrm{X}$

$\mathrm{X}$

$\mathrm{X}$

$\mathrm{X}$

$\mathrm{X}$

$\mathrm{X}$

$\mathrm{X}$

$\mathrm{X}$

$X$
$X$

$\mathrm{X}$

$\mathrm{X}$

$\mathrm{X}$

$\mathrm{X}$

X

X

$\mathrm{X}$

$X$
$X$

X

$\mathrm{X}$

X

$\mathrm{X}$
$\mathrm{X}$

$\mathrm{X}$

X

X

X

X

X

X $\quad X$

X $\quad X$

$\mathrm{X} \quad \mathrm{X}$

X

$X$

X X

$\mathrm{X}$

$\mathrm{X}$

X X

$\mathrm{X}-\mathrm{X}$

$\mathrm{X}$

$\mathrm{X}$

X

$\begin{array}{ccc}\mathrm{X} & \mathrm{X} & \mathrm{X} \\ & \mathrm{X} & \mathrm{X} \\ & & \\ \mathrm{X} & \mathrm{X} & \mathrm{X} \\ \mathrm{X} & & \mathrm{X} \\ \mathrm{X} & & \end{array}$

$X$
$X$
$X$

$\begin{array}{lll} & X & 5 \\ X & X & 3 \\ & X & 2 \\ X & 2 \\ X & 2 \\ & X & 6 \\ & X & 3 \\ & & \\ & & \\ & & \end{array}$


Spatio-temporal sequence of fires, including for prevention

Danger, risk, destructive potential

Fire placement

Planning, monitoring conditions prior to burning

Site preparation

Fire duration

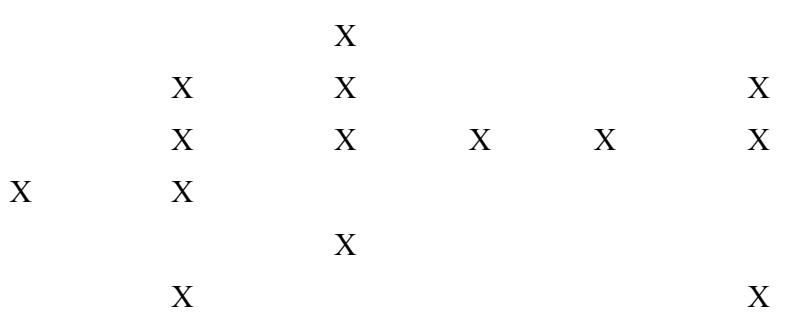

$\begin{array}{lll}X & X & 2 \\ X & 3 \\ X & 5 \\ X & 2 \\ X & 1 \\ X & 2 \\ & \end{array}$

Special clothing

\section{Fire Effects}

Fire effects on vegetation

Fire effects on animals

Consequences of not burning

Fire effects on soil

Smoke effects, smoke color, smoke column characteristics

Scorch height, bark char, smoked leaves

Fire effects on watershed, water delivery

Fire Governance, Other Social Factors

Burning illegal or regulated by central government

Gender roles in fire management

$\mathrm{X}$

$\mathrm{X}$

$\mathrm{X}$

$\mathrm{X} \quad \mathrm{X}$

$\mathrm{X}-\mathrm{x}$

$\mathrm{X}$

$\begin{array}{llll}X & X & X & X \\ X & X & X & \\ X & X & & X \\ X & & X \\ X & & \end{array}$

$\mathrm{X}$
$\mathrm{X}$
$\mathrm{X}$
$\mathrm{X}$
$\mathrm{X}$
$\mathrm{X}$
$\mathrm{X}$

Land stewardship, care, cleaning up country, controlling space

Knowledge transmission

Burning regulated internally by community

Fire as tool in social resistance, protest, local conflict

Authority, decision to burn

Age of participants

Prohibited areas (customary, sacred, community safety)

Number of elements recorded

$45 \quad 43$

$\mathrm{X}$

43

39

29

27

18

12

$\begin{array}{cc}\mathrm{X} & 8 \\ \mathrm{X} & 3 \\ \mathrm{X} & 5 \\ \mathrm{X} & 4 \\ \mathrm{X} & 3 \\ & 1 \\ \mathrm{X} & 1 \\ \mathrm{X} & 1 \\ \mathrm{X} & 1 \\ \mathbf{6 5} & \mathbf{6 6}\end{array}$


Table A.6. Elements of traditional fire knowledge recorded in studies from South America $(n=5)$.

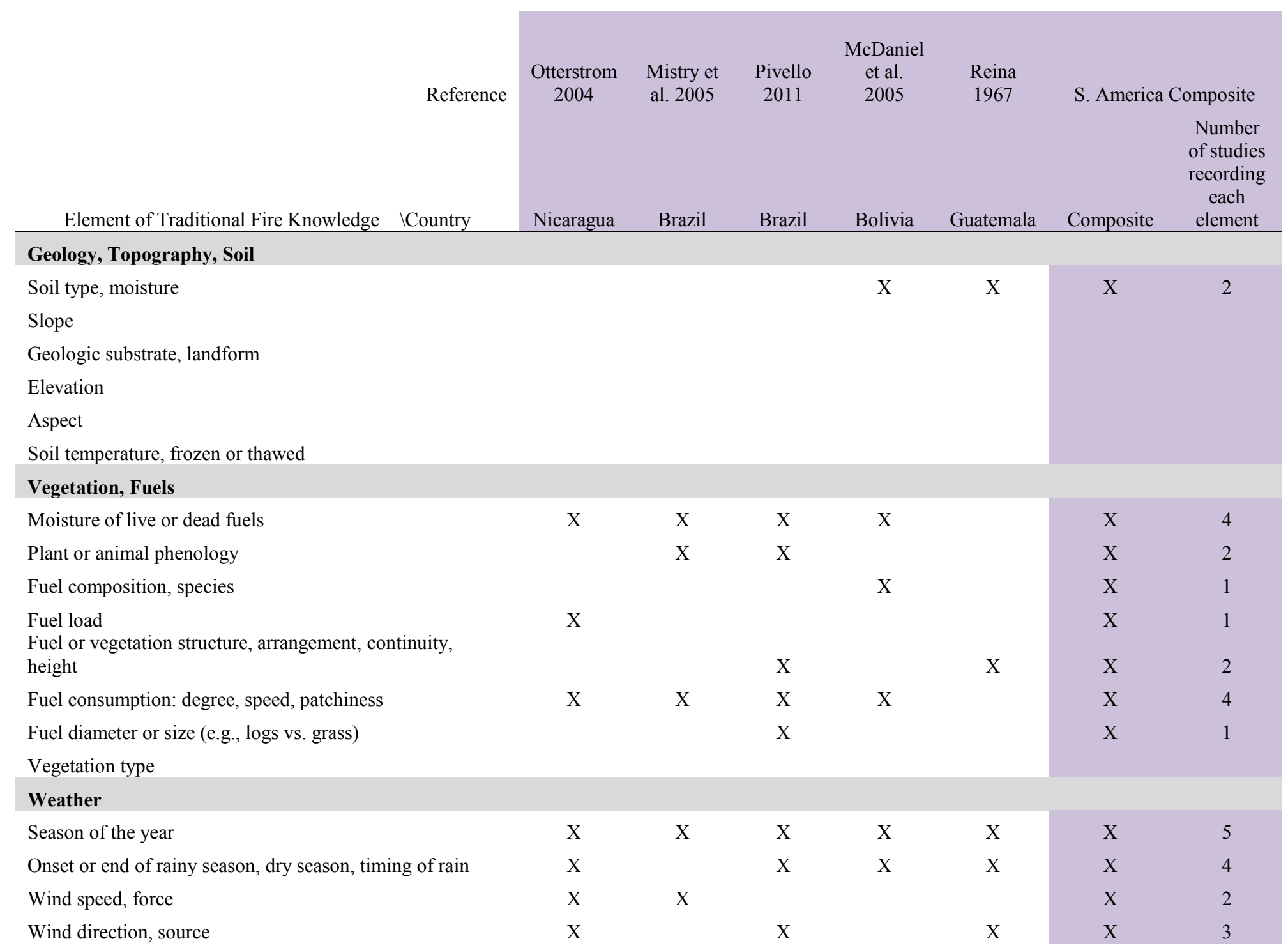


Temperature

Humidity of air, day

Water level, stream flow, river cycle

Quantity of rain

Snow or ice location, condition (including melting or

breakup)

Lightning

Phase of moon

Sun's force and position in sky

Clouds

\section{Fire Behavio}

Fire intensity, heat output (hot or cool fire)

Frequency, return interval, time since fire

Fire size, area, aerial extent

Fire type (surface, ground, canopy)

Backing, heading fire

Direction of fire spread (including landmarks)

Flame height

Rate of spread

Natural extinguishment

Residence time

Evenness, smoothness

Spotting, sparks, embers carried aloft

\section{Fire Operations}

\section{Fire control}

Firebreaks, barriers

Time of day

Landscape pattern, patch size

Tools for preparation, ignition, control

Crew size, use of neighbors

Ignition pattern

Spatio-temporal sequence of fires, including for prevention
$\mathrm{X}$

$\mathrm{X}$

$\mathrm{X}$

$\mathrm{X}$

X

$\mathrm{X}$

$\mathrm{X}$

\begin{tabular}{|l|l|}
\hline $\mathrm{X}$ & 1 \\
\hline $\mathrm{X}$ & 2 \\
\hline $\mathrm{X}$ & 1 \\
\hline $\mathrm{X}$ & 1 \\
& \\
\hline & \\
\hline $\mathrm{X}$ & \\
\hline $\mathrm{X}$ & \\
\hline $\mathrm{X}$ & 1 \\
\hline
\end{tabular}

$X \quad X$

$\begin{array}{llll}X & X & X\end{array}$

X

$\begin{array}{lll}X & X\end{array}$

X

X

\begin{tabular}{c|c}
$\mathrm{X}$ & 4 \\
$\mathrm{X}$ & 4 \\
$\mathrm{X}$ & 2 \\
\hline & \\
$\mathrm{X}$ & 3 \\
$\mathrm{X}$ & 1 \\
$\mathrm{X}$ & 2
\end{tabular}

2

$\begin{array}{ll}\mathrm{X} & \mathrm{X} \\ \mathrm{X} & \mathrm{X} \\ \mathrm{X} & \mathrm{X} \\ & \mathrm{X} \\ \mathrm{X} & \mathrm{X} \\ \mathrm{X} & \mathrm{X} \\ \mathrm{X} & \mathrm{X}\end{array}$

$\mathrm{X}$

$\begin{array}{ll}X & X \\ X & X \\ X & X \\ & X \\ & \\ & \end{array}$

\begin{tabular}{|l|l|l|}
$\mathrm{X}$ & $\mathrm{X}$ & 4 \\
$\mathrm{X}$ & $\mathrm{X}$ & 5 \\
$\mathrm{X}$ & $\mathrm{X}$ & 4 \\
& $\mathrm{X}$ & 2 \\
$\mathrm{X}$ & $\mathrm{X}$ & 3 \\
& $\mathrm{X}$ & 2 \\
$\mathrm{X}$ & $\mathrm{X}$ & 3 \\
& $\mathrm{X}$ & 1 \\
\hline
\end{tabular}


Danger, risk, destructive potential

Fire placement

Planning, monitoring conditions prior to burning

Site preparation

Fire duration

Special clothing

\section{Fire Effects}

Fire effects on vegetation

Fire effects on animals

Consequences of not burning

Fire effects on soil

Smoke effects, smoke color, smoke column characteristics Scorch height, bark char, smoked leaves

Fire effects on watershed, water delivery

\section{Fire Governance, Other Social Factors}

Burning illegal or regulated by central government

Gender roles in fire management

Land stewardship, care, cleaning up country, controlling space

Knowledge transmission

Burning regulated internally by community

Fire as tool in social resistance, protest, local conflict Authority, decision to burn

Age of participants

Prohibited areas (customary, sacred, community safety)
$\mathrm{X}$

\begin{tabular}{|c|l}
\hline $\mathrm{X}$ & 1 \\
\hline $\mathrm{X}$ & 1 \\
$\mathrm{X}$ & 2 \\
\hline
\end{tabular}

$\begin{array}{lll}X & X & X \\ X & X & X \\ X & X & \\ X & X & X\end{array}$

$\mathrm{X}$

$\mathrm{X}$

$\mathrm{X}$

$\mathrm{X}$

X 
Literature Cited in Appendices 1 and 2

Anderson, M. K. 2005. Tending the wild: Native American knowledge and the management of California's natural resources. University of California Press, Berkeley, California, USA.

Butz, R. J. 2009. Traditional fire management: historical fire regimes and land use change in pastoral East Africa. International Journal of Wildland Fire 18(4):442-450. [online] URL: http://www.publish.csiro.au/paper/WF07067

Cabrera-García, L. 2006. Linking social and ecological dynamics for bird conservation: protecting the endangered Sierra Madre sparrow in Chichinautzin, Mexico. Dissertation. McGill University, Montreal, Canada. [online] URL: http://digitool.Library.McGill.CA:80/R/?func $=$ dbin-jump-full\&object $\mathrm{id}=102793 \&$ silo_library $=$ GEN01

Eriksen, C. 2007. Why do they burn the 'bush'? Fire, rural livelihoods, and conservation in Zambia. Geographical Journal 173(3):242-256. [online] URL: http://onlinelibrary.wiley.com/doi/10.1111/j.1475-4959.2007.00239.x/abstract

Forbes, H. A. and H. A. Koster. 1976. Fire, axe, and plow: human influence on local plant communities in the southern Argolid. Annals of the New York Academy of Sciences 268:109-126. [online] URL: http://onlinelibrary.wiley.com/doi/10.1111/j.1749-6632.1976.tb47638.x/abstract

Garde, M., B. L. Nadjamerrek, M. Kolkkiwarra, J. Kalarriya, J. Djandjomerr, B. Birriyabirriya, R. Bilindja, M. Kubarkku, and P. Biless. 2009. The language of fire: seasonality, resources and landscape burning on the Arnhem Land Plateau. Pages 85-180 in J. Russell-Smith, P. Whitehead and P. Cooke, editor. Culture, ecology and economy of fire management in North Australian savannas: rekindling the Wurrk tradition. CSIRO Publishing, Collingwood, Victoria, Australia.

Grove, A. T. and O. Rackham. 2001. The nature of Mediterranean Europe: an ecological history. Yale University Press, New Haven, Connecticut, USA.

Haynes, C. D. 1985. The pattern and ecology of munwag: traditional Aboriginal fire regimes in north-central Arnhemland. Proceedings of the Ecological Society of Australia 13:203-214.

Hill, R., A. Baird, and D. Buchanan. 1999. Aborigines and fire in the wet tropics of Queensland, Australia: Ecosystem management across cultures. Society \& Natural Resources 12(3):205-223. [online] URL: http://www.tandfonline.com/doi/abs/10.1080/089419299279704

Hough, J. L. 1993. Why burn the bush? Social approaches to bush-fire management in West African national parks. Biological Conservation 65:23-28. [online] URL:

http://ezproxy2.library.colostate.edu:2099/10.1016/0006-3207(93)90192-4

Huffman, M. R. 2010. Community-based fire management at La Sepultura Biosphere Reserve, Chiapas, Mexico. Dissertation. Colorado State University, Fort Collins, Colorado, USA. [online] URL: http://discovery.library.colostate.edu/Record/DigiTool111267 
Kull, C. A. 2002. Madagascar aflame: landscape burning as peasant protest, resistance, or a resource management tool? Political Geography 21(7):927-953. [online] URL:

http://www.ingentaconnect.com/content/els/09626298/2002/00000021/00000007/art00054

Lake, F. K. 2007. Traditional ecological knowledge to develop and maintain fire regimes in northwestern California, Klamath-Siskiyou bioregion: management and restoration of culturally significant habitats. Dissertation. Oregon State University, Corvalis, Oregon, USA. [online] URL: http://hdl.handle.net/1957/6222

Laris, P. 2002. Burning the seasonal mosaic: Preventative burning strategies in the wooded savanna of southern Mali. Human Ecology 30(2):155-186. [online] URL:

http:/www.jstor.org/discover/10.2307/4603425?uid=3739568\&uid=2\&uid=4\&uid=3739256\&si $\underline{\mathrm{d}=21101098006821}$

Lewis, H. T. and T. A. Ferguson. 1988. Yards, Corridors, and Mosaics: How to Burn a Boreal Forest. Human Ecology 16(1):57-77. [online] URL: http://www.jstor.org/stable/4602869

Liacos, L. G. 1973. Present studies and history of burning in Greece. Pages 65-96 in Proceedings Annual Tall Timbers Fire Ecology Conference (Tallahassee, 1973). Tall Timbers Research Station, Tallahassee, Florida, USA.

Masipiqueña, A. B., G. A. Persoon, and D. J. Snelder. 2000. The use of fire in northeastern Luzon (Philippines): conflicting views of local people, scientists, and government officials. Pages 177-211 in R. Ellen, P. Parkes, and A. Bicker, editors. Indigenous environmental knowledge and its transformations, critical anthropological perspectives. Routledge, Taylor and Francis Group (second printing), London, England and New York, USA.

Maxwell, A. L. 2004. Fire regimes in north-eastern Cambodian monsoonal forests, with a 9300year sediment charcoal record. Journal of Biogeography 31(2):225-239. [online] URL: http://dx.doi.org/10.1046/j.0305-0270.2003.01015.x

Mbow, C., T. T. Nielsen, and K. Rasmussen. 2000. Savanna fires in east-central Senegal: Distribution patterns, resource management and perceptions. Human Ecology 28(4):561-583. [online] URL: http://www.jstor.org/stable/4603372

McDaniel, J., D. Kennard, and A. Fuentes. 2005. Smokey the tapir: traditional fire knowledge and fire prevention campaigns in lowland Bolivia. Society \& Natural Resources 18(10):921-931. [online] URL: http://www.tandfonline.com/doi/abs/10.1080/08941920500248921

Miller, A. M., I. J. Davidson-Hunt, and P. Peters. 2010. Talking about fire: Pikangikum First Nation elders guiding fire management. Canadian Journal of Forest Research 40:2290-2301. [online] URL: http://www.nrcresearchpress.com/doi/abs/10.1139/X10-177 
Mistry, J., A. Berardi, V. Andrade, T. Kraho, P. Kraho, and O. Leonardos. 2005. Indigenous fire management in the cerrado of Brazil: The case of the Kraho of Tocantins. Human Ecology 33(3):365-386. [online] URL: http://www.springerlink.com/content/m265t3070n841172/

Otterstrom, S. M. 2004. Fire in a Neotropical dry forest: cultural uses and ecological effects. Dissertation. University of California - Davis, Davis, California, USA. [online] URL: http://harvest.lib.ucdavis.edu/F/PH9HGM42L3177UL1G5BXHU9KJTL3GPCSPSJLEIHXTDY X7R2I64-32241? func=full-setset\&set number $=003335 \&$ set entry $=000002 \&$ format $=999 \&$ local base $=$ ucd 01 pub

Pivello, V. R. 2011. The use of fire in the cerrado and Amazonian rainforests of Brazil: past and present. Fire Ecology 7(1):24-39. [online] URL: http://fireecology.org/docs/Journal/pdf/Volume07/Issue01/024.pdf

Pyne, S. J. 1997. Vestal fire: an environmental history, told through fire, of Europe and Europe's encounter with the world. University of Washington Press, Seattle, USA.

Rai, N. D., C. M. Gowda, and S. Setty. 2007. Taragu Benki: fire use by Soliga adivasis in Biligiri Rangaswamy Temple Wildlife Sanctuary, Karnataka. Pages 87-89 in Rethinking forest fires: Proceedings of the national workshop on forest fires (New Dehli, India, November 13-14, 2007). Ashoka Trust for Research in Ecology and the Environment, New Delhi, India. [online] URL: http://www.atree.org/sites/default/files/Forest Booklet ver3.pdf

Reina, R. E. 1967. Milpas and milperos - implications for prehistoric times. American Anthropologist 69(1):1-20. [online] URL: http://onlinelibrary.wiley.com/doi/10.1525/aa.1967.69.1.02a00020/abstract

Rodgers, W. A. 1986. The role of fire in the management of wildlife habitats: a review. The Indian Forester 112:845-857.

Russell-Smith, J., D. Lucas, M. Gapindi, B. Gunbunuka, N. Kapirigi, G. Namingum, K. Lucas, P. Giuliani, and G. Chaloupka. 1997. Aboriginal resource utilization and fire management practice in Western Arnhem Land, monsoonal Northern Australia: notes for prehistory, lessons for the future. Human Ecology 25(2):159-195. [online] URL:

http://www.jstor.org/stable/4603235

Setty, R. S., K. Bawa, T. Ticktin, and C. M. Gowda. 2008. Evaluation of a participatory resource monitoring system for nontimber forest products: the case of Amla (Phyllanthus spp.) fruit harvest by Soligas in South India. Ecology and Society 13(2):19. [online] URL: http://www.ecologyandsociety.org/vol13/iss2/art19/

Stewart, O. C., H. T. Lewis, and K. Anderson. 2002. Forgotten fires: Native Americans and the transient wilderness. University of Oklahoma Press, Norman, Oklahoma, USA.

Therik, T. 2000. The role of fire in swidden cultivation: a Timor case study. Pages 77-79 in J. Russell-Smith, G. Hill, S. Djoeroemana, and B. Myers, editors. Fire and Sustainable Agricultural and Forestry Development in Eastern Indonesia and Northern Australia; Proceedings of an 
international workshop held at Northern Territory University, Darwin, Australia, 13-15 April 1999. Australian Centre for International Agricultural Research, Northern Territory University, Darwin, Australia.

Turner, N. J. 1999. "Time to Burn." Pages 185-218 in R. Boyd, editor. Indians, Fire and the Land in the Pacific Northwest. Oregon State University Press, Corvallis, Oregon, USA.

Vélez, R. 2005. La población rural en la prevención de incendios forestales. United Nations Food and Agriculture Organization, Rome, Italy.

Yibarbuk, D., P. J. Whitehead, J. Russell-Smith, D. Jackson, C. Godjuwa, A. Fisher, P. Cooke, D. Choquenot, and D. M. J. S. Bowman. 2001. Fire ecology and Aboriginal land management in Central Arnhem Land, Northern Australia: a tradition of ecosystem management. Journal of Biogeography 28:325-343. [online] URL: http://www.jstor.org/stable/2656198 